
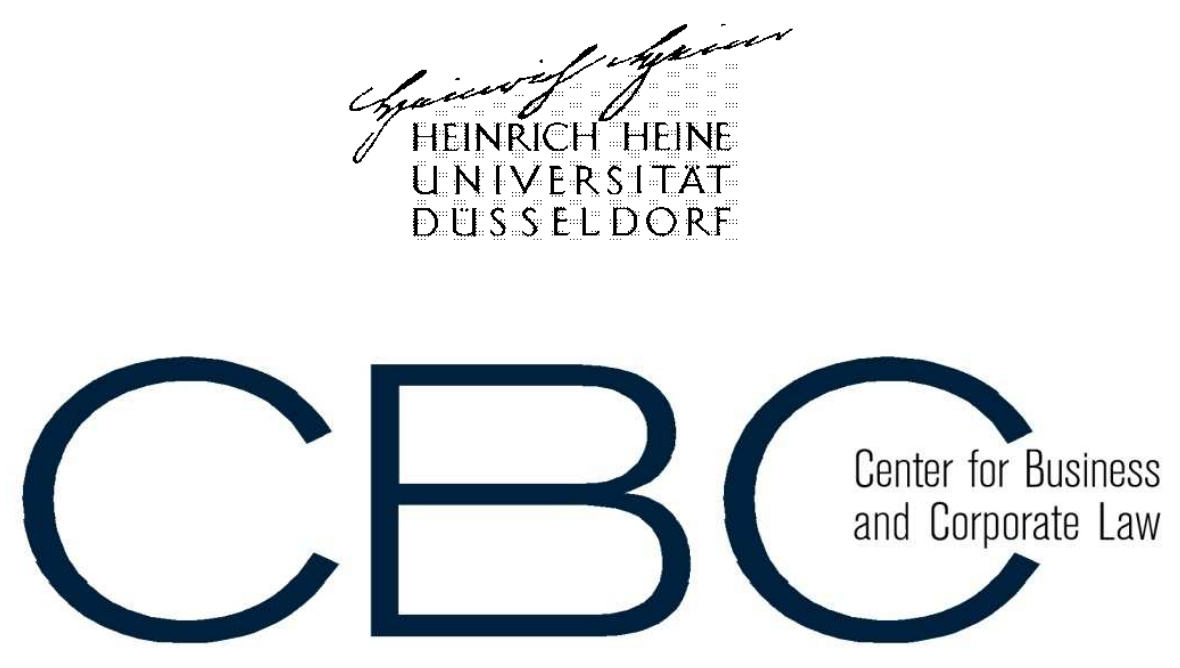

Heinrich-Heine-Universität Düsseldorf

- Juristische Fakultät -

Arbeitspapiere des Instituts für Unternehmensrecht (IUR)

Heinrich-Heine-University Duesseldorf / Germany

- Faculty of Law -

Center for Business and Corporate Law Research Paper Series (CBC-RPS)

http://iur.duslaw.eu/de

Autor / Author (E-Mail): $\quad$ Dr. Dirk Zetzsche, LL.M. (Toronto)

E-Mail: $\quad$ Dirk.Zetzsche [at] uni-duesseldorf.de

Titel / Title: $\quad$ Challenging Wolf Packs: Thoughts on Efficient Enforcement of Shareholder Transparency Rules

CBC Nummer / Number: 0044 (2/2010)

SSRN Nummer / Number: $\quad$ http://ssrn.com/papers=1428899

Schlagworte / Keywords: Shareholder activism, hedge funds, private equity funds, hidden ownership, empty voting, enforcement, announcement effect, Premium Claim, derivatives, contracts of differences, equity swaps, cartels, leniency, antitrust, takeovers, whistle blowing, protected disclosure, mandatory bid, change of control, wolf pack.

JEL Classifications: $\quad$ G14, G21, G23, G24, G34, K21, K22, K42 


\title{
Challenging Wolf Packs: Thoughts on Efficient Enforcement of
}

\section{Shareholder Transparency Rules}

\author{
Dirk Zetzsche ${ }^{1}$
}

\section{[Draft as of 3 February 2010]}

\begin{abstract}
The key issue concerning shareholder transparency rules, and the related rules on acting in concert (Europe), or the voting group concept (U.S.) is enforcement. Rather than thinking about appropriate enforcement measures, jurisdictions such as the UK and Switzerland decided in favor of Economic Ownership Disclosure. The current debate in the U.S., on the European and national level of some European jurisdictions is moving in the same direction. This article examines a different option which is the better enforcement of existing transparency rules. In order to counter secret acquisition strategies, similar to antitrust leniency and "protected disclosure" (i.e. whistle blowing) rules, governments are best advised to assign a reward for disclosure.
\end{abstract}

Under the reward model presented here, the initial stock price reaction reflects the value of the information previously hidden from the market. The first participant of a scheme who discloses the holdings of all scheme participants is to be assigned the difference between the price of the target's voting shares ex ante and ex post disclosure, calculated on the basis of the participants' joint holdings of shares (Announcement Premium). Distinguishing between schemes based on the equity value of the parties involved (Equity Strategy) - commonly referred to as wolf packs - and schemes where an acquirer seeks to create a large stake based on derivatives (Service Strategy), assigning the Announcement Premium to the first entity disclosing the scheme's holding and intentions is likely to counter Equity Strategies efficiently. The Service Strategy is countered effectively by granting the Announcement Premium to agents that act on behalf of the intermediaries (i.e. to bank employees).

Keywords: Shareholder activism, hedge funds, private equity funds, hidden ownership, empty voting, enforcement, announcement effect, Premium Claim, derivatives, contracts of differences, equity swaps, cartels, leniency, antitrust, takeovers, whistle blowing, protected disclosure, mandatory bid, change of control, wolf pack.

1 Dr. iur, LL.M. (Toronto), Faculty of Law, Heinrich Heine University Duesseldorf, Germany. The author is grateful for comments provided by Daniel Awrey, Paulo Câmara, Brian Cheffins, Paul Davies, Martin Gelter, Joshua Getzler, Kristoffel Grechenig, Carsten Jungmann, Gerd van den Klijs, Joe McCahery, Georg Ringe, Gerd Smits, Klaus-Ulrich Schmolke, Alexander Stremitzer, Christoph Thole, Tobias Tröger, John Vella, Ulrich Wackerbarth, Kay Zetzsche and participants of conferences and workshops at the University of Amsterdam, University of Bonn, University of Cambridge, Heinrich Heine University Duesseldorf, University of Oxford, Tilburg University. 
[C]ovenants, without the sword, are but words and of no strength to secure a man at all

(Thomas Hobbes, Leviathan, 1651, Pt 2, Chap XVII "Of the causes, generation, and definition of a commonwealth", If 2, p. 85; reprint by OUP: Oxford World Classic, p. 111)

Table of Contents

A. Introduction 4

B. The Dilemma - Adverse Incentives in a Multiparty Environment 12

I. The Equity Strategy: Wolf Packs __ 12

1. Key Driver: Equity Value __ 13

2. Co-ordinated Efforts__ 14

II. The Service Strategy 15

1. Co-ordination by Derivatives _ 15

2. Key Drivers 18

III. Disclosure vs. Economic Incentives __ 20

C. Inefficiency of Traditional Enforcement___ 21

I. Co-relation of Ex ante and Ex post Enforcement ___ 23

II. Ex post enforcement: No Market-Based Pricing __ 24

III. Burden of Proof _ 25

D. A Reward Model __ 26

I. The Antitrust Analogy __ 27

II. Key Assumptions ___ 33

III. Defining the Premium __ 34

IV. The Equity Strategy 37

1. Expected Future Pay-Off 37

2. Correlation of Premium Claim with joint shareholding _ 38

3. Infinite Secret Acquisitions Game _ 39

4. Bonding __ 44

v. The Service Strategy 44

1. Originator Unlikely to Disclose __ 44

2. Financial Intermediaries: Premium to Corporate Entity __ 45

3. Premium to Individuals (Agents, Employees) ___ 47

E. Facing the Real World __ 49

I. Anticipating Early Disclosure __ 49

II. Determining the Announcement Premium __ 51

III. Enforcing the Premium Claim _ 51

IV. Exploiting the System \& Constitutional Concerns __ 53

1. Reduced deterrence by lower fines?

2. Benefits from Violating the Law?

3. Benefits for the Originator? 56 
V. The Issue of Overenforcement 57

1. Erroneous convictions?

2. A Better world? 58

3. Borderline activity? 59

F. Other Types of Inside Information? __ 60

G. Conclusion _ 60

\section{A. Introduction}

The efficacy of mandatory disclosure of shareholder transparency rules is at the forefront of the current policy agenda and receives significant attention in academia. Across the globe, much effort is devoted to designing wide-ranging disclosure rules. This article takes a different stance by promoting the idea that current rules suffer from weak enforcement $^{2}$ which is facilitated by market surveillance problems ${ }^{3}$ rather than poor legal design. Since deterrence is a combination of the penalty and the probability of being caught, ${ }^{4}$ this article seeks to add insights as to how Government's decision in favor of mandatory disclosure of major

${ }^{2}$ Reinhard H. Schmidt, Gerald Spindler, FINANZINVESTOREN AUS ÖKONOMISCHER UND JURISTISCHER PERSPEKTIVE (transl. Financial investors from an economic and legal perspective), Nomos: 2008, at p. 250 \198, arguing that proving acting in concert is "incredibly difficult."; Michael Schouten, The Case for Mandatory Ownership Disclosure in Europe - Empty Voting, Hidden Ownership and the Transparency Directive, Stanford Journal of Business, Law \& Finance (2009) - draft on SSRN, at 34, 37 et seq. (highlighting the issues surrounding the application of existing rules); Dirk A. Zetzsche, Hidden Ownership in Europe: BAFin's Decision in Schaeffler v. Continental (2009) 10:1 European Business Organization Law Review (EBOR) 115.

${ }^{3}$ Central Counterparty (CCP) Clearing for over-the-counter (OTC) derivatives may reduce the market surveillance problems. A CCP interposes itself between the buyer and the seller of a derivative security. When trading through a CCP, the single contract between two initial OTC counterparties is replaced by two new contracts - between the CCP and each buyer and seller of the OTC contract. This structure improves the management of counterparty risk. Moreover, it allows the CCP to perform multilateral netting of exposures and payments. Finally, it increases transparency by gathering information on market activity and exposures in the hands of the CCP, which may be made available to regulators and the public. See $C$ Ledrut, $C$ Upper, Changing post-trading arrangements for OTC Derivatives", (2007) Bank for International Settlements (BIS) Quarterly Review, 12/07, pp 83-95; Stephen G Cecchetti / Jacob Gyntelberg / Marc Hollanders, Central counterparties for over-the-counter derivatives, (2009) BIS Quarterly Review, 9/09, at 45. Some later activities towards CCP clearing for derivatives include the initiative by U.S. Secretary of the Treasury Timothy Geithner, "Regulatory Reform Over-The-Counter (OTC) Derivatives" (13 May 2009, tg-129), available at http://www.ustreas.gov/press/releases/tg129.htm (February 2010), requiring clearing of all standardized OTC derivatives through regulated CCPs, and the Consultation by the Committee of European Securities Regulators (CESR), Trade Repositories in the European Union, CESR/09-837 (September 2009).

${ }^{4}$ Gary S. Becker, Crime and Punishment, (1968) 76:2 Journal of Political Economy 169. 
shareholdings can be enforced most efficiently in the case of certain hidden acquisition strategies. Looking - in Garrett Hardin's terms - for a "technical solution" 5 to the compliance problem, it develops and analyzes a reward model of shareholder transparency rules based on antitrust leniency, traditional whistle blowing and crown witness schemes.

While major acquisitions by one party may be appropriately detected and sanctioned by enforcement agencies, given the documentation associated with it on the side of investment banks, regulators face insurmountable difficulties when enforcing transparency rules in the case of certain hidden acquisition strategies. This article identifies two of these different strategies subject to enforcement issues. The first strategy hereafter referred to as Equity Strategy is an equity-based technique, commonly referred to as 'wolf pack strategy': the acquirer teams up with other acquirers. Each of the participants purchases a share of the target's equity which is close to, yet below, the disclosure threshold for shareholdings. In most cases, regulators cannot prove the team effort since the coordination is based on oral agreements. The second technique hereafter referred to as Service Strategy is based on service contracts with a multitude of investment banks. The acquirer enters into derivative contracts according to which the investment bank acquires a significant share in the target, but the economic exposure of these shares is vested in the acquirer. The rights stemming from these shares, if not in its favor, will not be used against the acquirer. At a point in time prior to, or following the takeover bid, the shares will be transferred to the acquirer. While the contracts reveal the economic characteristics of the derivative, the documentation typically lacks any side agreement relating to how the investment bank is expected to vote, as well as how and when the shares will be transferred to the acquirer. Consequently, a lot of speculation surrounding the true content of the respective agreements is characteristic of the Equity and the Service Strategy.

While in many ways incomplete, regulators have made both of the above techniques subject to disclosure rules. Under US laws, the above

\footnotetext{
${ }^{5}$ Garett Hardin, The Tragedy of the Commons, (1968) 162 Science 1243.
} 
schemes may account for deemed beneficial ownership under the rules promulgated under Section 13(d) of the Securities and Exchange Act of 1934 (Rule 13d-3(a) and (b)). ${ }^{6}$ In Europe, for purposes of the shareholder transparency rules of Artt. 9 et seq. of the EC Transparency Directive, and for the threshold prompting a mandatory bid under Art. 5 of the EC Takeover Directive, shares held for the equity-based strategy may meet the ,acting in concert' test under the laws of EC Member States. The service-based strategies may meet the requirements of an 'implicit agreement' under Art. 13 of the EC Transparency Directive according to which the acquirer may mandate delivery of the shares held by the investment banks, or may be qualified as shares 'held on behalf of' the target under Art. 10g) of the EC Transparency Directive. ${ }^{7}$

Some regulators have reduced, or intend to reduce, the uncertainty surrounding broad-phrased disclosure rules. They did so by requiring mandatory disclosure not only of shareholdings carrying voting rights, but also of economic positions that do not carry voting rights (hereafter 'Economic Ownership Disclosure'). ${ }^{8}$ Economic Ownership Disclosure, however, has other downsides: Any strengthening of shareholder disclosure rules is likely to reduce investment in information about the true

\footnotetext{
${ }^{6} 17$ II Code of Federal Regulations (CFR) § 240.13d-3.

${ }^{7}$ For details, see Dirk A. Zetzsche, Hidden Ownership in Europe: BAFin's Decision in Schaeffler v. Continental, (2009) 10:1 EBOR 115, at 132.

${ }^{8}$ For the UK see Financial Services Agency, DISCLOSURE AND TRANSPARENCY RULES (DISCLOSURE OF CONTRACTS FOR DIFFERENCES) INSTRUMENT 2009, prepared by Policy Statement PS 09/3 - Feedback on CP08/17 and final rules (March 2009); Disclosure of Contracts for Differences - Feedback and Policy Statement on CP07/20, CP08/17 (October 2008); Policy Update on Disclosure of Contracts for Difference (July 2008), and Disclosure of Contracts for Difference, Consultation Paper 07/20 (November 2007), all available at: http://www.fsa.gov.uk. The rules requiring disclosure of certain positions from Contracts for Difference (CfDs) came into force on 1 June 2009. For Switzerland see Art. 20(2bis) BEHG of the Swiss law on Stock Exchanges and Securities Trading (BEHG) and Artt. 11, 13(1) of the Ordinance of the Swiss Banking Commission on Stock Exchanges and Securities Trading (BEHV-EBK); C.H. Von der Crone, E. Bilek and M. Hirschle, 'Neuerungen im Offenlegungsrecht' (New Developments regarding Disclosure Rules), 80 Schweizerische Zeitschrift für Wirtschaftsrecht (SZW) (2008) pp. 1 and 4; U. Bertschinger, 'Finanzinstrumente in der Aktienrechtsrevision - Derivate, Securities Lending und Repurchase Agreements' (Financial Instruments and the Reform of Corporate Law - Derivatives, Securities Lendung and Repurchase Agreements), SZW 80 (2008) pp. 208 et seq.; P. Nobel, 'Neues Aktienrecht' (The New Corporate Law), 80 SZW (2008) pp. 175 and 188 et seq. In addition, the European Parliament commissioned a study on the issues of hidden ownership and empty voting which has been submitted at the end of October 2009.
} 
value of an issuer: ${ }^{9}$ Disclosure of a major shareholding signals underpricing of the said shares at the stock markets. Shareholders that do not invest in information may freeride on the signal provided by said disclosure. In turn, the stock price increases which renders the takeover more costly. In addition, management may launch defensive measures early on, or even prior to the takeover bid which render the takeover post disclosure even more expensive as compared to defensive measures being launched after a significant or even a controlling stake is acquired. Consequently, if disclosure rules are too stringent, fewer buying opportunities are identified and fewer takeover offers are being launched. Mitigating takeover activity, in turn, reduces the disciplining effect of takeovers on management, in general. As life gets easier for management, agency costs are likely to increase, ${ }^{10}$ which is detrimental to (at least) the interests of dispersed stockholders. This is particularly true as potential acquirers are not tied to the public stock markets. As a response to Economic Ownership Disclosure, potential acquirers may make profitable acquisitions in the private equity or commodity domain. The departure of these investors may also reduce liquidity of the stock markets. Reduced liquidity is likely to have a negative impact on both the price discovery function and price sensitivity of the stock markets. In short: If disclosure is too strict, the marginal benefits of disclosure are negative.

This article examines a different option by developing a model that induces participants to reveal the content of the respective agreements

\footnotetext{
${ }^{9}$ S. Grossman \& J. Stiglitz, On the Impossibility of Informationally Efficient Markets, 70 Amer. Econ. Rev. 393, 405 (1980).

${ }^{10}$ Other arguments against broad-phrased disclosure rules include potential law suits and discouragement of overall monitoring: European Commission, Report on More Stringent National Measures Concerning Directive 2004/109/EC on the Harmonisation of Transparency Requirements in Relation to Information About Issuers whose Securities are Admitted to Trading on a Regulated Market, SEC (2008) 3033 final (2008), at 10; $H$. Fleischer and K. Schmolke, 'Kapitalmarktrechtliche Beteiligungstransparenz nach $21 \mathrm{ff}$. WpHG und "Hidden Ownership"' (Securities law-based Transparency of Shareholdings under ss. 21 et seq. WpHG and Hidden Ownership) 29 (33) Zeitschrift für Wirtschaftsrecht (ZIP) (2008) p. 1501 et seq.; Jonathan R. Macey \& Jeffrey M. Netter, Regulation 13D and the Regulatory Process, 65 Wash. U.L.Q. 131, 144 (1987); Bernhard Black, Next Steps in Corporate Governance Reform: 13D Reuls and Control Person Liability, in: K. Lehn \& R. Kamphuis eds., MODERNIZING US SECURITIES REGULATION: ECONOMIC AND LEGAL PERSPECTIVES (1992), at 201 (raising concerns that institutional investors may be discouraged from monitoring).
} 
entered into in the vicinity of an acquisition of a large shareholding, or a takeover bid, respectively.

Part B analyzes the two main strategies to prepare for acquisitions secretly, which is referred to herein as Equity and Service Strategy. It shows that disclosure of major shareholdings runs counter to the scheme participants' incentives. Upon disclosure, the target's stock price is expected to experience significant abnormal returns. I refer to this effect as Announcement Premium. Acquirers who otherwise need to pay a higher stock price for further acquisitions avoid paying the Announcement Premium to the sellers by maintaining secrecy. The investment banks financing the deal have reason to be concerned that the transaction will fail if the Announcement Premium is significant and the acquirers' stake is small, due to a higher price for the target's shares. In addition, investment banks can be expected to lose clients in future transactions if they disclose the acquisition on their own.

Part C holds that traditional enforcement of shareholder transparency rules is ineffective. Effectiveness of ex ante enforcement ${ }^{11}$ relies on ex post enforcement. The available sanctions either deprive shareholders of a bid altogether, or of the market test that a lawfully disclosed acquisition would provide. Most importantly, traditional enforcement does not overcome issues associated with the burden of proof. Since documentation is scarce, regulators are limited to speculation which rarely withstands a critical review in court.

Part D presents a reward model for the enforcement of shareholder transparency rules. The remainder of the article adjusts the model assumptions to reflect real world conditions.

Due to inefficient enforcement, refraining from disclosure results in a collusive equilibrium. An efficient regime is to increase the costs for participants' remaining silent to a level where it exceeds the costs of early disclosure. At the same time, the participants have the best knowledge about the scheme, they may disclose at the cheapest costs of all market

\footnotetext{
${ }^{11}$ Ex ante enforcement as used herein refers to all measures that seek to detect and deter future infringements of the law. See infra, C. I.
} 
participants. Yet they have the weakest incentives to do so. In that regard, the situation is analogous to antitrust cartels. In contrast to cartels, however, in the Equity and the Service Strategy participants have no incentives to defect. Moreover, the limited period of time for making the respective strategy work makes it harder to detect the hidden activities. The incentives for going public must be greater, in relative terms, than conventional leniency is able to offer.

In order to overcome the disincentives for disclosure, I propose a rewardbased enforcement model. Pursuant to that model, the Announcement Premium from the joint shares of all participants is assigned to the first party who discloses the scheme and the related intentions of the participants (hereafter referred to as Premium Claim). The larger the share collectively held by participants, the greater the incentive for disclosure. The Premium Claim creates a Prisoner's Dilemma among participants (albeit that communication among them is possible).

For the Equity Strategy, my model most likely results in an equilibrium under which no participant is willing the scheme's collective holdings to surpass disclosure thresholds for fear of defection by fellow participants that seek to cash-in the Premium Claim. The law can render countermeasures such as requiring security for participation void at low costs. For the Service Strategy, due to reputational restraints, the financial intermediaries involved come close to game theory's perennial players. Banks defecting by early disclosure is unlikely. Thus, I suggest to assign the Premium Claim to the agents (in particular, the employees) of the core intermediaries involved in the Service Strategy. My model increases the costs of secrecy and the likelihood of disclosure for both the Service and the Equity Strategy.

In order to provide an apt focus, this article willfully disregards a number of questions related to mandatory disclosure and takeovers, in general: This article does not address the question of whether takeovers are beneficial. Takeovers are a legally accepted way in which control in an issuer may change hands and advanced jurisdictions provide for a procedural setting to that effect. Ethical or economic qualifications of takeovers are beyond 
the scope of this article. Nor does this article discuss whether disclosure of shareholdings, or related conduct, is efficient or desirable. While the criticism regarding transparency of major shareholdings does not go unnoticed, it is not the aim of this article to reconsider Manne's arguments against mandatory disclosure, in general, ${ }^{12}$ or other theories holding that market prices aptly reflect any - direct or indirect - increase in shareholdings by investors, or that disclosure rules on major shareholdings (alike other types of inside information ${ }^{13}$ ) cannot add any further benefit to market efficiency ${ }^{14}$ and / or investor protection. ${ }^{15}$ In addition, this article does not analyze how stock prices respond to disclosure of major shareholdings. While previous research has shown significant abnormal (short-term) returns upon first-time disclosure of major shareholdings, ${ }^{16}$ it is not the task of this article to analyze the how

${ }^{12}$ Henry G. Manne, Henry, Insider Trading and the Stock Market, New York: The Free Press, 1966.

${ }^{13}$ In a non-technical meaning, the discussion is about undisclosed inside information. See for the trading on negative vs. positive inside information Kristoffel Grechenig, The Marginal Incentive of Insider Trading: An Economic Reinterpretation of the Case Law, (2006) University of Memphis Law Review 37, 75; an overview of empirical analyses on trading patterns on inside information provide M. King \& A. Roell, Insider trading, in: (1988) Economic Policy 6, 163; Dolgopolov, Insider trading and the bid-ask spread: a critical evaluation of adverse selection in the market setting, (2004) Cap. U. L. Rev. 33, 83.

${ }^{14}$ For example, this may be due to insiders voluntarily disclosing or forwarding inside information, or specialized analysts detecting inside information; for the former see Stephen Bainbridge, The Insider Trading Prohibition: A Legal and Economic Enigma, (1986) 38 U. Fla. L. Rev. 35, at 43 pp.; Roberta Romano, Empowering Investors: A Market Approach to Securities Regulation, (1998) 107 Yale L.J. 2359, 2373 pp.; for the latter Meulbroek, An Empirical Analysis of Illegal Insider Trading, (1992) 47 Journal of Finance 1661.

${ }^{15}$ For example, Merritt B. Fox, Civil Liability and Mandatory Disclosure (2009) 109 Colum. L. Rev. - forthcoming (on SSRN), at 17.

${ }^{16}$ Although the premium for passive investors is smaller, this is true for all types of investor types: For potential buyers: WH Mikkelson \& RS Ruback, An Empirical Analysis of the Interfirm Equity Investment Process, (1985) J. Finan. Econ. 14, 523 (1985); Clifford G. Holderness \& Dennis P. Sheehan, Raiders or Saviors? The Evidence on Six Controversial Investors, (1985) 14 J. Fin. Econ. 555 (1985); Steven R. Bishop, Pre-Bid Acquisitions and Substantial Shareholder Notices, (1991) 16 Australian J. Manage 1 (1991); for activist investors / hedge funds: Along Brav, Wei Jiang, Frank Partnoy, Randall Thomas, Hedge Fund Activism, Corporate Governance, and Firm Performance, (2008) Journal of Finance 63:4, 1729-75; abnormal returns of 5\% - 7\% within 20 days; April Klein, Emanuel Zur, Hedge Fund Activism, London 2007: abnormal returns of $10 \%$ within 30 days; Mark Mietzner, Denis Schweizer, Hedgefeonds and Private Equity: Differences in Value Creation, Oestrich-Winkel (EBS), 2008: abnormal returns with 2 times 20 days; Robin M. Greenwood \& Michael Schor, Investor Activism and Takeovers (2008), at 29, available at SSRN: http://ssrn.com/abstract=1003792. For 
and why of this stock price reaction in-depth. Moreover, this article does not explore extensively the question of how shareholder transparency rules are or should be designed, in order to cover long positions stemming from the use of derivatives and other types of indirect shareholdings associated with the terms hidden ownership and empty voting ${ }^{17}$ - a question that is widely discussed, ${ }^{18}$ due to some high profile cases, inter alia, in the U.S. ${ }^{19}$, the UK ${ }^{20}$ and Germany. ${ }^{21}$ Finally, this article does not

passive investors: Christopher Clifford, Value Creation or Destruction? Hedge Funds as Shareholder Activists (2007), available at SSRN: http://ssrn.com/abstract=971018, at 42 (comparing s. 13D and 13G filings, showing a premium of $1.74 \%$ for passive and $3.44 \%$ for active investors). These studies are confirmed by 2006 announcements surveyed by the Financial Services Agency, Disclosure of Contracts for Differences, Consultation and Draft Handbook Text (CP 07/20) (2007), annex 3, p. 14. For informed traders who are unlikely to pursue activist strategies (such as mutual funds): See Aslihan Bozcuk \& M. Ameziane Lasfer, The Information Content of Institutional Trades on the London Stock Exchange, 40 J. Finan. Quant. Anal. 621, 631 (2005); Bishop, ibid, at 19.

${ }^{17}$ H.C. Hu and B.S. Black, 'Hedge Funds, Insiders, and the Decoupling of Economic and Voting Ownership: Empty Voting and Hidden (Morphable) Ownership', $13 \mathrm{~J}$. Corp. Fin. (2007) p. 343; 'The New Vote Buying: Empty Voting and Hidden (Morphable) Ownership', 79 South. Cal. L. Rev. (2006) p. 811; 'Empty Voting and Hidden (Morphable) Ownership: Taxonomy, Implications, and Reforms', 61 Bus. Lawy. (2006) p. 1011; 'Equity and Debt Decoupling and Empty Voting II: Importance and Extensions, 156 U. Pa. L. Rev. (2008) p. 625; 'Debt, Equity, and Hybrid Decoupling: Governance and Systemic Risk Implications', 14 Europ. Fin. Man. (2008) p. 663; 'Empty Voting and Hidden (Morphable) Ownership', M\&A Lawyer (March 2007) at pp. 9-12; 'Debt and Hybrid Decoupling: An Overview', The M\&A Lawyer, Vol. 1 (April 2008) pp. 4-10.

18 See, for example, European Parliament, Resolution of 23 September 2008 with Recommendations to the Commission on Transparency of Institutional Investors, European Parliament (2007/2239(Ini)) (2008); Roberta S. Karmel, Voting Power Without Responsibility or Risk - How Should Proxy Reform Address the Decoupling of Economic and Voting Rights?, (2010) 55 Villanova Law Review - forthcoming; Michael Schouten, The Case for Mandatory Ownership Disclosure in Europe - Empty Voting, Hidden Ownership and the Transparency Directive, Stanford Journal of Business, Law \& Finance - forthcoming.

${ }^{19}$ See U.S. District Court for the Southern District of New York, 11 June 2008, Case 1:08cv-02764-LAK - CSX v. The Children's Investment Fund (TCI) -, confirmed by summary order No. 08-2899-cv (2nd Cir. Sept. 15, 2008). See also J. Coffee, 'Regulators Need to Shine a Light on Derivatives', Financial Times (30 June 2008) p. 13. The question of civil damages for "short-swing" profits under s. 16(b) of the SEA was settled for \$11 Mio while CSX had identified potential recoverable damages of approx. $\S 138$ Mio, see Theodore Mirvis, Hedge Funds Settle "Short Swing" Profits Litigation, Harvard Law School Corporate Governance Blog, 28 December 2008.

${ }^{20}$ See Tom Siebens \& Melissa Gambol, "Who's hiding behind the hedges? Developments in the USA and UK may limit use of total return swaps to conceal equity stakes in public companies, (2009) Capital Markets Law Journal 4:2, 172-178.

${ }^{21}$ For the Schaeffler - Continental Case (Germany) Dirk A. Zetzsche, Hidden Ownership in Europe: BAFin's Decision in Schaeffler v. Continental (2009) 10:1 European Business Organization Law Review (EBOR) 115. A legislative proposal is presented by Theodor Baums \& Maike Sauter, Anschleichen an Übernahmeziele mittels Cash Settled Equity Derivaten - ein Regelungsvorschlag, ILF_WP_097 (2/ 2009), online http://www.llffrankfurt.de/uploads/media/ILF_WP_097.pdf (last visited Nov 2009). For an overview of 
make any suggestions as to which stock price is fair in the takeover context. While there may be a significant level of (noisy) trading in the vicinity of takeovers assuming the acquirer's willingness to raise the price of the first bid, it is not the task of this article to question the legal assumption that transparency of major shareholdings supports fair market prices. $^{22}$

\section{B. The Dilemma - Adverse Incentives in a Multiparty Environment}

This article seeks to add insights as to how we can improve compliance with existing shareholder transparency rules. Shareholder transparency rules mandate acquirers to disclose if their (joint) share surpasses certain thresholds provided by securities law. ${ }^{23}$ Circumventing these disclosure rules enables shareholders to secretly build up a significant stake in an issuer whose shares are traded at regulated markets. For this purpose, acquirers employ - separately, or jointly, as the case may be $-{ }^{24}$ two types of strategies: the Equity Strategy (infra B.I.), or the Service Strategy (infra B.II.).

\section{The Equity Strategy: Wolf Packs}

The first strategy is an equity-based technique.

the legislative developments see Michael Schouten \& Mathias M. Siems, The Evolution of Ownership Disclosure Rules across Countries (on SSRN).

${ }^{22}$ Recital (1) of the Directive 2004/109/EC, OJ L 390/38 (2004) ('Transparency Directive') states: "The disclosure of accurate, comprehensive and timely information about security issuers builds sustained investor confidence and allows an informed assessment of their business performance and assets. This enhances both investor protection and market efficiency." Recital (2) refers specifically to disclosure of major shareholdings. To what extent the rules fulfill this assumption, is subject to debate among experts. See, for example, Eilis Ferran, BUILDING AN EU SECURITIES MARKET (Cambridge University Press: 2004), at 127 pp.; Michael Schouten, The Case for Mandatory Ownership Disclosure in Europe - Empty Voting, Hidden Ownership and the Transparency Directive, Stanford Journal of Business, Law \& Finance (forthcoming) - draft on SSRN, at 5.

${ }^{23}$ US securities law requires disclosure of beneficial ownership of at least $5 \%$ of the issuer's voting rights; Under the European Transparency Directive, Participant States may set thresholds not exceeding $5 \%$ of the voting rights. Some states such as Italia require disclosure starting at $1 \%$ of the voting rights.

${ }^{24}$ In CSX ./. TCI (supra n. 19), TCI held a large stake of up to $14 \%$ indirectly based on the Service Strategy, while TCl was acting in concert with another hedge fund (G3) that held approx. $5 \%$ of CSX shares. 


\section{Key Driver: Equity Value}

The key feature of the Equity Strategy is that each participation is driven by an expected increase in the value of a participant's stake in the issuer. This increase may be the result of either the announcement effect, ${ }^{25}$ or a potential restructuring of the firm pursued by existing management under the pressure exerted by the acquirer ${ }^{26}$ or by new management following a takeover of the firm. ${ }^{27}$

If an acquirer seeks to take over the company, it may accrue additional benefits by remaining silent and disregarding disclosure rules: Under the European mandatory bid-rule of Article 5 of the Takeover Directive ${ }^{28}$ upon assembling a stake that carries control (which is, in most cases, defined as the acquisition of $30 \%$ or one-third of the issuer's voting rights), ${ }^{29}$ participants are required to issue a mandatory bid for all outstanding shares at a price that relates to the weighted average stock price for a certain period of time prior to the bid, and that is at least as high as the highest price previously paid to another seller (at the stock exchange or beyond). ${ }^{30}$ Given that the share price increases upon announcement of

\footnotetext{
${ }^{25}$ See references supra n. 16.

${ }^{26}$ This was the likely driver of TCl's strategy in CSX ./. TCI (supra n. 19).

${ }^{27}$ Please note that takeovers do not constitute the usual behavior of hedge funds.

${ }^{28}$ Directive 2004/25/EC of the European Parliament and of the Council of 21 April 2004 on takeover bids; OJ L 142/12-23 (30 April 2004).
}

${ }^{29}$ See Article 5 (3) of Directive 2004/25/EC, supra n. 28: "The percentage of voting rights which confers control for the purposes of paragraph 1 and the method of its calculation shall be determined by the rules of the Participant State in which the company has its registered office." For details across Participant States see European Commission, Report on the Implementation of the Directive on Takeover Bids, SEC (2007) 268, at Annex 2 (acquisition of $30 \%$ of voting rights required by Austria, Belgium, Cyprus, Germany, Finland, Ireland, Italy, The Netherlands, Spain, Sweden, UK; one-third of the voting rights require Portugal, Slovakia, Luxembourg and France).

${ }^{30}$ See Article 5 (4) of Directive 2004/25/EC, supra n. 28: "The highest price paid for the same securities by the offeror, or by persons acting in concert with him/her, over a period, to be determined by Participant States, of not less than six months and not more than 12 before the bid referred to in paragraph 1 shall be regarded as the equitable price. If, after the bid has been made public and before the offer closes for acceptance, the offeror or any person acting in concert with him/her purchases securities at a price higher than the offer price, the offeror shall increase his/her offer so that it is not less than the highest price paid for the securities so acquired. Provided that the general principles laid down in Article 3(1) are respected, Participant States may authorise their supervisory authorities to adjust the price referred to in the first subparagraph in circumstances and in accordance with criteria that are clearly determined. To that end, they may draw up a list of circumstances in which the highest price may be adjusted either upwards or 
the major shareholding, creating a large stake prior to disclosure reduces the minimum price for the mandatory bid. In the U.S., where acquisition of control does not prompt a mandatory bid, but management may engage in takeover defenses, the same is true if the secretly assembled stake grants control over the company. Given that control has changed hands and that enforcement is inefficient, management's defensive measures are useless. Management can be expected to step aside with no further opposition.

\section{Co-ordinated Efforts}

In order to secure the above benefits, the acquirer teams up with other acquirers. Each of the participants purchases a share of the target's equity which is close to, yet below, the disclosure threshold for major shareholdings.

\section{Fig 1: The Equity Strategy}

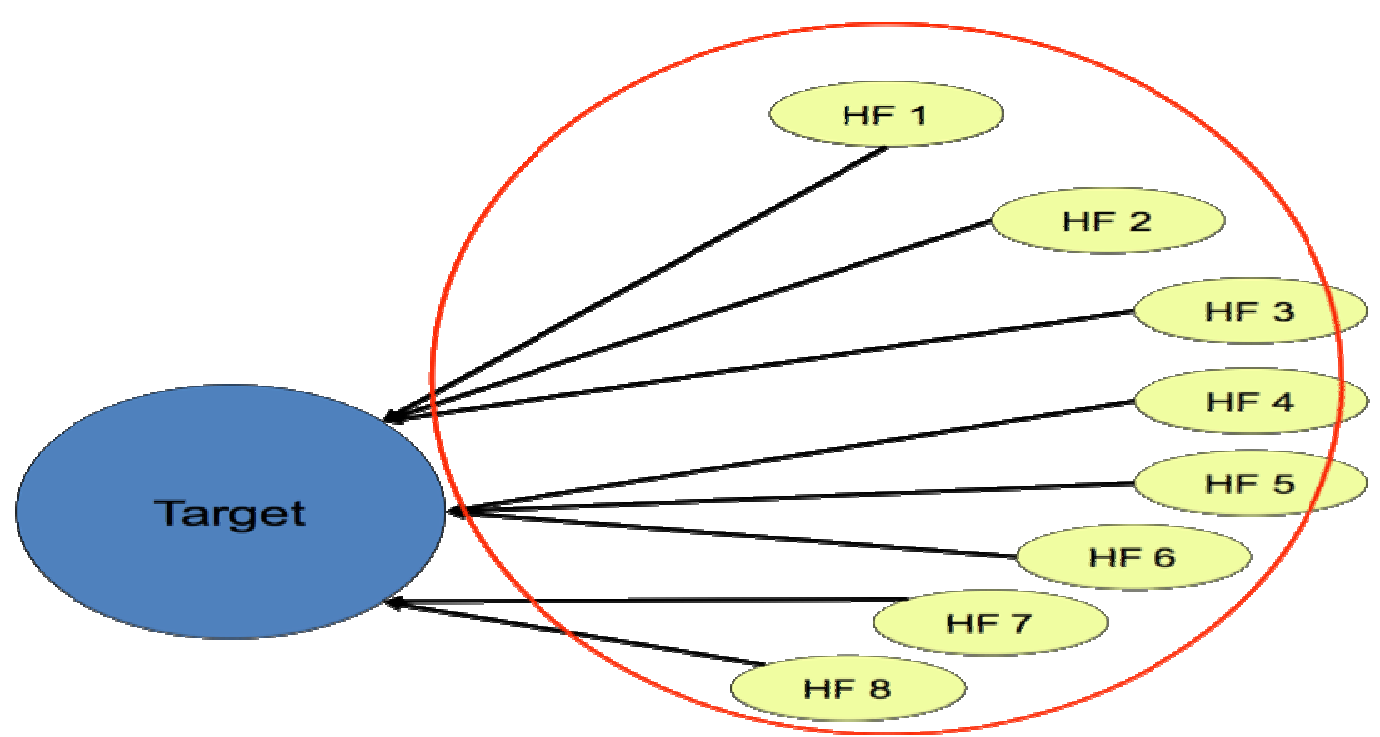

This article is not about drafting new rules but enforcing existing ones; it does not take a stand in the discussion surrounding the beneficial or harmful effects regarding mandatory disclosure of acting in concert, or

downwards, for example where the highest price was set by agreement between the purchaser and a seller, where the market prices of the securities in question have been manipulated, where market prices in general or certain market prices in particular have been affected by exceptional occurrences, or in order to enable a firm in difficulty to be rescued. They may also determine the criteria to be applied in such cases, for example the average market value over a particular period, the break-up value of the company or other objective valuation criteria generally used in financial analysis." 
voting groups. While not all jurisdictions subject all forms of cooperation to mandatory disclosure, ${ }^{31}$ the conduct hereafter referred to as Equity Strategy describes a situation in which the cooperation among acquirers of shares must be disclosed under the respective national laws if it is to meet the disclosure threshold while each participant's stake stays below the disclosure threshold.

\section{The Service Strategy}

\section{Co-ordination by Derivatives}

Under the Service Strategy the acquirer / originator of the scheme enters into derivative contracts with investment banks which lead, perfect information given, to a legal situation in which the share hedges held by the investment banks count as shares held by the acquirer for the purposes of disclosure rules. Again, while the total accumulated stakes held by different investment banks exceed the disclosure threshold, each bank's stake stays below the disclosure threshold.

For example, the Service Strategy may be employed by entering into Contracts for Difference / Cash-settled Total Return Equity Swaps with the acquirer taking the long leg and investment banks the short leg of the swap. ${ }^{32}$ Under such a swap agreement, two cash flows stemming from reference values are exchanged, or 'swapped'. The swap of cash flows is taking place at some point in the future and, as such, the future value of at least one of the underlying assets will be unknown at the time each leg of the swap is established. Typically, one reference value is that of a virtual bond whose yield refers to state bank lending terms - at the Euro Interbank Offered Rate (EURIBOR) or the London Interbank Offered Rate $(\mathrm{LIBOR})+\mathrm{x} \%$ - while the other reference value is cash flow from a quoted

${ }^{31}$ See for the U.S. *; for Europe European Commission, Report on More Stringent National Measures Concerning Directive 2004/109/EC on the Harmonisation of Transparency Requirements in Relation to Information About Issuers whose Securities are Admitted to Trading on a Regulated Market, SEC (2008) 3033 final (2008), at 10; CESR, Summary of responses to Questionnaire on Transposition of the Transparency Directive,CESR/08-514b (2008).

${ }^{32}$ For a primer on swaps see Stuart Greenbaum \& Anjan Thakor, Contemporary Financial Intermediation, $2^{\text {nd }} \mathrm{Ed}$. (AP, 2007), at 323 et seq. As a result of industry coordination through organizations such as the ISDA, total resturn equity swaps have been highly standardized. 
stock (e.g. the target's shares) reflected in its stock price and dividends respectively. One swap party - the 'Short Party' - pays out the difference between the cash flows to the other swap party - the 'Long Party' - when the stock price increases, while the Long Party makes good to the short party any loss in value when the stock price decreases. Normally, investment banks function as professional swap counterparties. The banks are not interested in bearing the risk stemming from the derivative contract. In order to even out its risk, the Short Party may enter into derivative contracts with other banks, or purchase the underlying shares. In addition to the Long Party's obligations stemming from the swap itself, an investment bank receives interest on the capital invested for its hedges, and swap fees for running the swap (infra Figure 2).

Fig 2: Contracts for Differences ('CFD’) / Cash-settled Total Return Equity Swap:

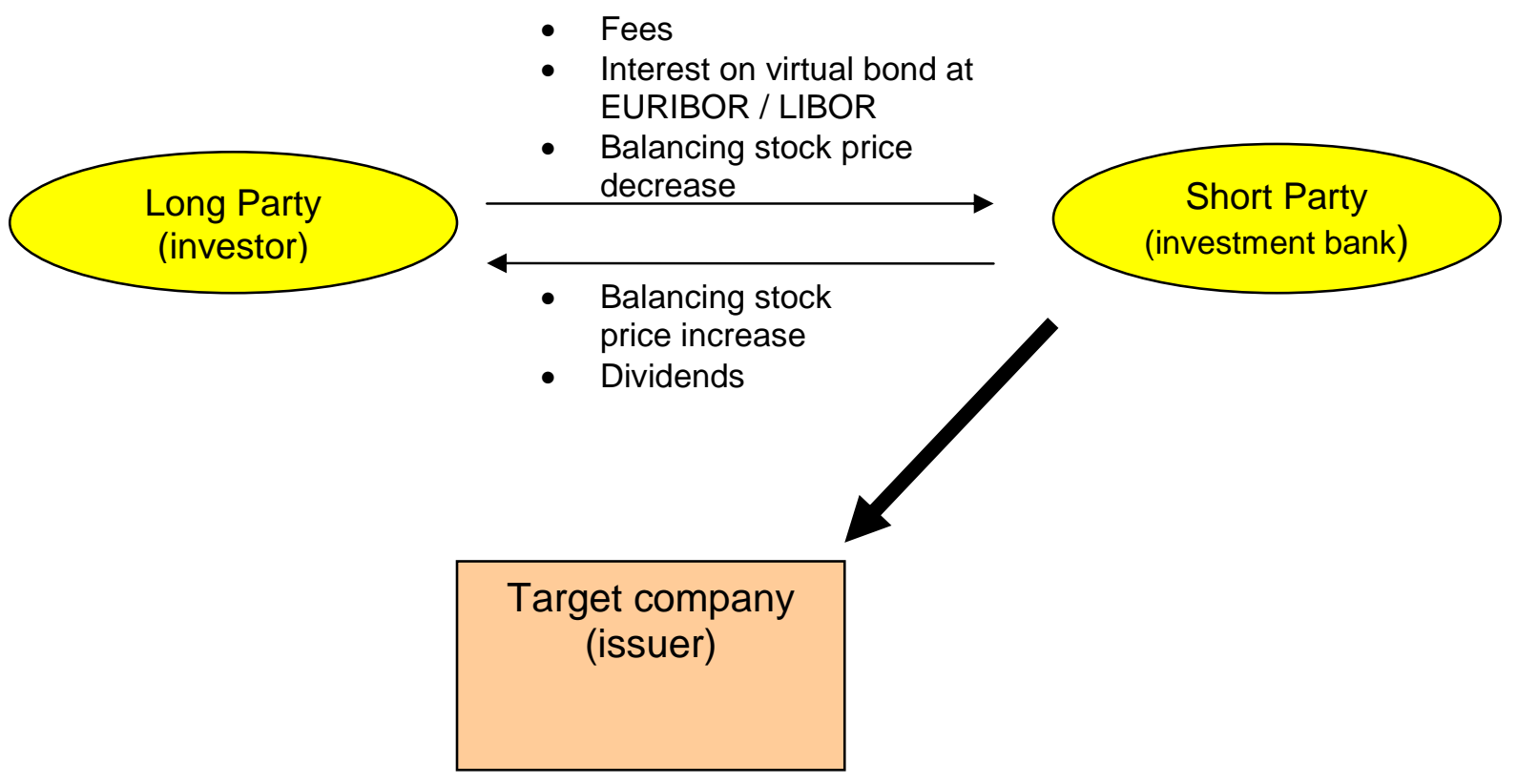

In ordinary swap agreements a Short Party to a swap does not need to hold the shares (although it may want to for hedging purposes). It is within the context of the Service Strategiy that the Short Party will invariably hold the shares, while the Long Party bears the economic risk. The Short Party is generally deemed shareholder under the respective disclosure rules. Traditional U.S. and European disclosure rules do not cover the Long 
Party's sole economic exposure ${ }^{33}$ instead, they require some additional influence over the voting power of the underlying shares. ${ }^{34}$ While the legal qualification may vary, the same economic characteristic may be achieved with any type of derivative contract, in particular with put and call options.

If the acquirer seeks to avoid disclosure rules, it may create a derivative scheme (infra Figure 3) for a significant part of the target's shares with one investment bank (hereafter referred to as Core Intermediary). The Core Intermediary holds a stake below the disclosure threshold itself, and is hedged by derivative contracts with other investment banks (Int 1; Int N), which in turn hold stakes below the disclosure threshold. The acquirer's joint economic stake comprises its own direct shares plus the shares held indirectly via the core intermediary (the "Total Return Equity", denoted as $X)$. By virtue of oral, 'gentlemen's agreements, the acquirer may influence how the banks vote.

${ }^{33}$ For the Economic Ownership Disclosure rules in Switzerland and England see supra $\mathrm{n}$. 8.

${ }^{34}$ For the U.S., see Rule 13d-3(a) under the Securities Exchange Act, 17 C.F.R. 240.13d3(a): "A beneficial owner of a security includes any person who, directly or indirectly, through any contract, arrangement, understanding relationship, or otherwise has or shares: (i) voting power which includes the power to vote, or to direct the voting of, such security; and/or, (ii) investment power which includes the power to dispose, or to direct the disposition of, such security; the accepted interpretation of Art. 7 sent. 1 No. 1 of the (first) Transparency Directive 88/627/EC and Art. $10 \mathrm{~g}$ of the (second) Transparency Directive among German securities lawyers is that a contractual scheme will lead to the short counterparty holding shares on the long counterparty's behalf if the long party (1) bears the economic risk of the underlying shares, and (2) is capable of influencing how voting rights are exercised, see A. Koppensteiner, Appendix to s. 20 AktG, Commentary to ss. 21 et seq. WpHG, in U. Noack and W. Zöllner, eds., Kölner Kommentar zum Aktiengesetz, 3rd edn., at n. 18; U.H. Schneider, Commentary to s. 22 WpHG, in H.D. Assmann and U.H. Schneider, eds., Wertpapierhandelsgesetz, 4th edn. (Cologne, Otto Schmidt, 2006) at n. 45; for Portugal see the interpretation of s. 20a of the Portuguese Securities Code by the Portuguese securities regulator CMVM in re Portugal Telecom and Semapa, see http://web3.cmvm.pt/sdi2004/emitentes/docs/FR3120.pdf. 
Fig 3: Service Strategy with Cash-settled Total Return Equity Swap / CFD ${ }^{35}$

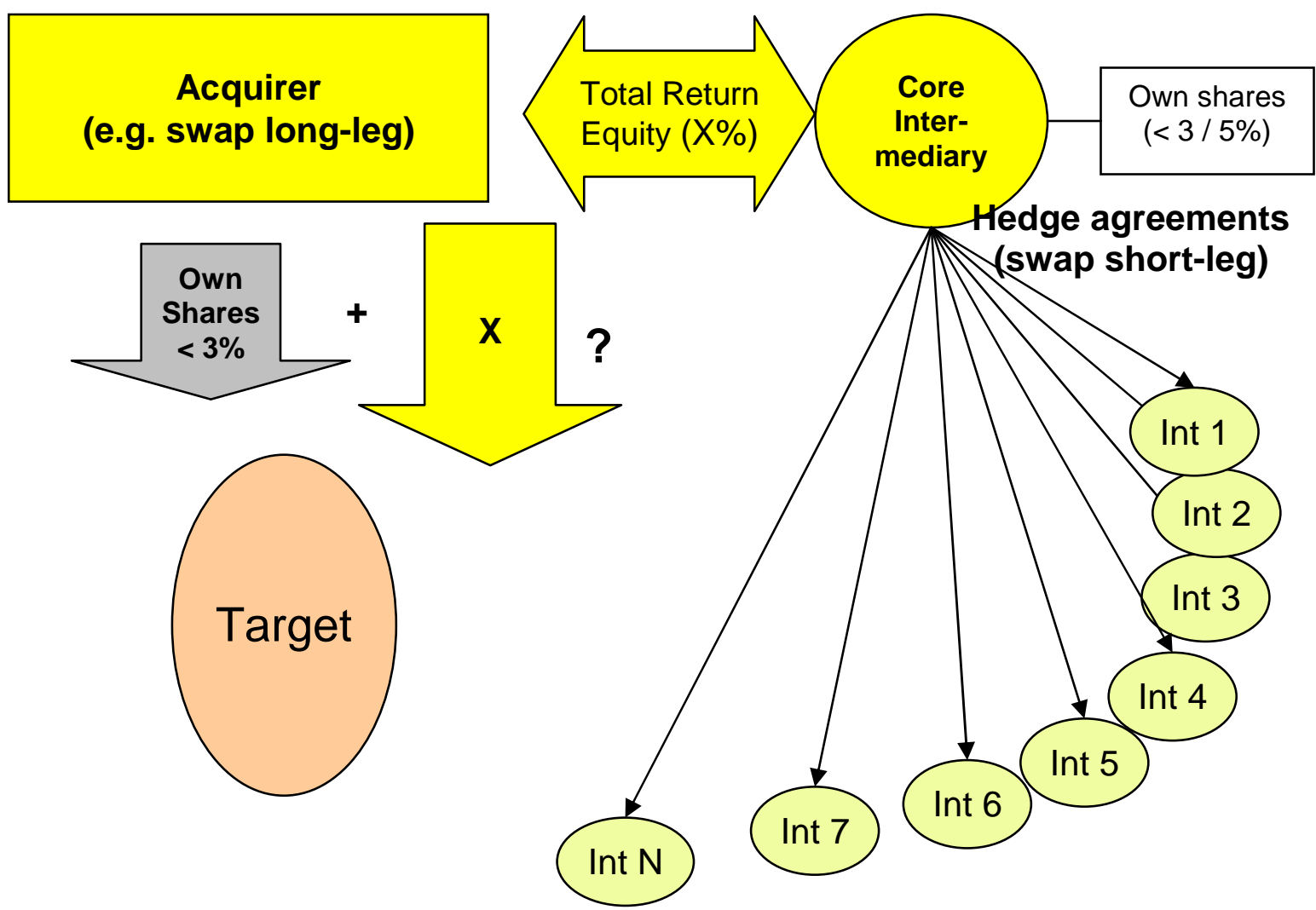

Please note that not all of the investment banks (Int 1; Int N) need to know what is happening. However, it is likely that the core intermediary is aware of what the acquirers aspire to achieve; this is particularly true if the derivative position held by the core intermediary on behalf of the acquirers exceeds certain limits. ${ }^{36}$ While the Long Party could enter into derivative contracts with all intermediaries itself, it needs to manage multiple hedging relationships and make sure that none of the positions, together with the proprietary trading positions, and the positions of other clients of the respective intermediaries, exceed the disclosure threshold. Handling this requires skill and effort, both of which exist at investment banks. From the perspective of the acquirer, there is also the added benefit of anonymity.

\section{Key Drivers}

The acquirer's incentives are essentially the ones provided by the equity scheme (supra B.I.1.); however, the incentives to maintain secrecy are

\footnotetext{
${ }^{35}$ Based on Schaeffler's scheme preparing for the takeover of Continental AG.

${ }^{36}$ It is said to be customary in the City of London that the Long Party explains its motives to the Short Party when the long positions exceed a stake of $15 \%$ of the issuer's equity.
} 
greater when compared to a straight-forward acquisition based on the fact that the originator's position in the target's share is leveraged due to the derivative contracts.

In contrast, the core intermediary's position regarding the target is hedged (supra B.Il.1.). The core intermediary benefits neither from an increasing, nor a decreasing stock price. Being involved in, or running, a derivative scheme constitutes a viable business strategy itself. The same is likely to be true for the investment banks (Int $1 ; \operatorname{Int} N)$; these banks seek to sell out the risk from the short-leg of the swap to clients that wish to hold a short position in said stocks.

The investment banks' benefits comprise of four factors:

(1) The longer the derivative scheme is maintained, the greater is the investment bank's profit: Swap fees are typically a fraction of the swap value at the beginning and at the termination of the swap. If the parties agree on value-based swap fees, the banks benefit to a small extend from the increase in the value of the target's stock. ${ }^{37}$ Moreover, creating the derivative-based scheme will require time. It is estimated that an acquirer can purchase up to a third of the daily trading volume without significantly impacting on the market price, and without the markets and the issuer noticing. Investment banks will increase the overall positions piece by piece. The total swap amount entered into and thus the fees charged to the client early in the scheme is small as compared to the fees charged at a latter point in time. The more stocks are subject to the swap scheme, the greater the investment bank's profit. Finally, also note that drafting the respective derivative contracts is costly; negotiating these contracts for the first time induces the largest share of transaction costs. From the bank's perspective derivative schemes exhibit significant economies of scale.

(2) The same argument applies to the interest that the Long Party pays: in the absence of defaults and deteriorating credit risk, the longer the

\footnotetext{
${ }^{37}$ Whether the swap fees are based on the market value which fluctuates over time or the notional amount which is fixed by agreement - in most cases it is the value of the underlying assets at the day the swap is executed - is subject to the parties' discretion. In client specific contracts as those provided by ISDA, the swap fees are calculated on the basis of the notional amount. In addition to these swap fees, a value-based entry and exit fee is charged on British-style CFD platforms.
} 
derivative contract is maintained and the larger the overall swap volume, the greater the investment bank's profit is.

(3) During or following the takeover, most acquirers need acquisition finance. While we currently experience difficulties in the market for acquisition finance due to the financial crisis, ${ }^{38}$ acquisition finance was a profitable banking market in the past, and it may be one in the future.

(4) Finally, client-orientation adds to the bank's reputation as serviceoriented entity. Since the people involved can be expected to be intertwined with other business entities, the advantages of a client-oriented reputation may exceed the circle of clients. For example, we frequently see the names of Merrill Lynch ${ }^{39}$ and Deutsche Bank ${ }^{40}$ in large-scale derivative transactions.

\section{Disclosure vs. Economic Incentives}

The above incentives depend, to a certain extent, on secrecy. Upon early disclosure, a sudden stock price increase that is greater than expected may force the acquirers to terminate the transaction, for lack of financing or since the new stock price reflects the firm's intrinsic value. In this case, the acquirer's previous investments in information and acquisition finance (interests, swap fees etc.) are lost. Moreover, since the acquisition of additional shares requires a greater investment when compared to a state of non-disclosure, the announcement premium prompted by early disclosure reduces the benefits of the overall transaction. (Early)

38 See Kaplan/Stromberg, Leveraged Buyouts and Private Equity (2008), online http://www.ssrn.com/abstract=1194962; as a result, acquirers seek to avoid living up to their promises which explains why more M\&A deals are terminated. See for example Hexion Specialty Chemicals, Inc., v. Huntsman Corp., C.A. No. 3841-VCL (Del. Ch. Sept. 29, 2008).

${ }^{39}$ FIAT-IFIL-EXOR (Italy); Schaeffler ./. Conti (Germany); Porsche AG's acquisition of Volkswagen AG (Germany).

40 Perry v. Ithaca (Custodians) Ltd, Court of Appeal, New Zealand, Perry Corporation v. Ithaca (Custodians) Ltd, 4 November 2003, [2005] Part 4 Case 11 [NZCA]; CSX v. TCI. (supra n. 19); the merger of Compaq and Hewlett Packard (U.S.): In August 2003, the SEC fined Deutsche Bank for failing to disclose to its mutual fund investors a material conflict of interest with regard to its vote on the proposed HP/Compaq merger. The success of the merger depended on the vote. See 'SEC Brings Settled Enforcement Action Against Deutsche Bank Investment Advisory Unit in Connection with Its Voting of Client Proxies for Merger Transaction; Imposes \$750,000 Penalty', SEC (19 August 2003), available at http://www.sec.gov/news/press/2003-100.htm. 
disclosure also impacts on the investment banks: if the risk of termination materializes, the profits from the derivative scheme end, and the bank is prevented from further capitalizing on the economies of scale associated with derivative schemes (supra B.II.). Moreover, unsuccessful transactions do not require acquisition finance and do not add to the banks' reputation to the same extent as successful transactions do.

Mandatory disclosure of major shareholdings runs counter to the incentives of all parties involved in the Equity or Service Strategy. It seems that all participants are better off if secrecy can be maintained, and the timing of disclosure is determined by the parties' plans rather than by law.

While this is true within the context of individual transactions, there exists a larger question ${ }^{41}$ as to whether this state of affairs ultimately translates into a net benefit to these parties. Specifically, to the extent that this state of affairs will sometimes mean that the scheme participants will be outsiders to these transactions (and thus losers), there exists the theoretical possibility that they may end up being net losers. This calculus will of course be complicated by the fact that, while the scheme participants will be able to calculate the potential benefits of being insiders with some degree of precision, they will face severe informational problems when calculating the potential costs of being outsiders. Under these conditions it is likely that the parties think - only this is important! that remaining is the best option they have.

\section{Inefficiency of Traditional Enforcement}

The above considerations disregard one important aspect of the participants' calculations - enforcement. As ancient Thomas Hobbes realized, "there must be some coercive power to compel men equally to the performance of their covenants by the terror of some punishment greater than the benefit they expect by the breach of their covenant." ${ }^{, 42}$ Regulatory risk may prove costly. These costs include expenses for legal

\footnotetext{
${ }^{41}$ Thanks to Dan Awrey for this insight.

${ }^{42}$ Thomas Hobbes, Leviathan, 1651, Pt 1, Chap XV "Of other laws of nature”, ๆ3, p. 71; reprint by OUP: Oxford World Classic, p. 95).
} 
defense, time and effort for dealing with regulators, and sanctions such as fines, criminal sanctions, or civil liability. ${ }^{43}$ However, only efficient enforcement is capable of countering the economic incentives for maintaining secrecy by imposing additional costs on wrongdoers which ultimately deter wrongdoers. Does traditional enforcement meet this requirement?

While the applicable tools vary from jurisdiction to jurisdiction, ${ }^{44}$ enforcement that seeks to detect secret acquisition strategies prior to their disclosure (ex ante enforcement) comprise of 1) market surveillance by arithmetic models through which regulators seek to detect suspicious trading patterns in stock markets, 2) obligations imposed on investment firms and / or their managers to comply, and 3) case-specific examination of rumors. The latter may be pursued by questioning individuals who are deemed to be involved. Enforcement action after disclosure of significant shareholdings (ex post enforcement) may result in sanctions such as forfeiture of shareholder rights, civil damages, administrative and sometimes even criminal sanctions. Variants of ex post enforcement constitute the cooling-off period, i.e. a regulator bans the acquirer from issuing a bid, or further acquisition of shares. Some regulators may also require the participants to sell their shares (over the stock exchange, or to someone else, as the case may be). In addition, financial intermediaries and other entities subject to licensing may lose their license for financial services; the individuals involved may be subject to director disqualification and/or administrative or criminal sanctions.

\footnotetext{
${ }^{43}$ For example, s. 16 (b) of the U.S. Securities Exchange Act of 1934 provides for recovery of short-wsing profits stemming from violation of disclosure rules by the issuer. For an example in the CSX ./. TCI ase, see Mirvis, Hedge Funds Settle "Short Swing" Profits Litigation, 28 December 2008 (The Harvard Corporate Governance Blog).,.For Germany, it is argued that (former) shareholders may engage in securities litigation, see $H$ Hirte in $\mathrm{H}$. Hirte in Hirte \& Möllers (eds.), Kölner Kommentar zum Wertpapierhandelsgesetz, (Cologne, Heymanns, 2007), Commentary to s. 21 of the Securities Trading Law, at n. 196; UH Schneider, Introduction to ss. 21 et seq. WpHG, in H.D. Assmann and U.H. Schneider, eds., Wertpapierhandelsgesetz, 4th edn. (Cologne, Otto Schmidt, 2006), at n. 16.

${ }^{44}$ See for the US *; for the UK *; for Germany *; for Canada *; for Switzerland *; for the Netherlands *.
} 
Traditional enforcement of shareholder transparency rules does not turn the incentives against disclosure into a pro-disclosure situation.

\section{Co-relation of Ex ante and Ex post Enforcement}

Under the strategies described above, the individual's intentions and the inter-personal relationship between different legal entities mandates disclosure. Even assuming that technical devices would provide for perfect market oversight - which is not the case for a number of reasons relating to the chain of intermediaries that act worldwide on behalf of multiple clients $-{ }^{45}$, without information on the subjective side (i.e. the participants' plans and intentions), enforcement reveals different entities acquiring a number of shares which may be related to each other, or not. Trading patterns rarely reflect these personal relationships clearly.

With respect to compliance and unsophisticated whistle blowing rules, ${ }^{46}$ compliance, or blowing the whistle, will only come into practice if the unlawful behavior is likely to be (severely) sanctioned at a later point in time or if the incentives of the whistle-blower sufficiently diverge from those of the firm which they represent. In the absence of sanctions being provided in the future, from the perspective of the financial services firm, the risk-adjusted profit from complying is Zero, while the economic and reputational loss is significant. The same is true on the individual level:

\footnotetext{
${ }^{45}$ With respect to shareholder identification, I Gómez-Sancha Trueba, "Indirect holdings of securities and exercise of shareholder rights (a Spanish perspective)", (2008) 3 Oxford University Capital Markets Law Journal 32; M Kahan \& E Rock, "The Hanging Chads of corporate voting,", (2008) 96 The Georgetown Law Journal 1227; Paul Myners, Review of the impediments to voting UK shares - report to the Shareholder Voting Working Group (1/2004), while improvements are reported in the 2008 update; RC Nolan, "Indirect Investors: A Greater Say in the Company?", (2003) 3:1 Journal of Corporate Law Studies 73; Matthias Siems, Convergence in Shareholder Law (Cambridge University Press: 2008), at 133-138; Dirk A. Zetzsche, Shareholder Passivity, Cross-Border Voting and the Shareholder Rights Directive, (2008) 8:2 Journal of Corporate Law Studies 289.

${ }^{46}$ See James Fanto, Whistleblowing and the Public Director: Countering Corporate Inner Circles, (2004) Oregon L. Rev. 83:2, 435; Kristoffel Grechenig, Positive and Negative Information - Insider Trading Rethought, in: Gregoriou/Ali, Insider Trading - Global Developments and Analysis (CRC Press 2009) 245, chapter 15.6. The 1998's British Public Interest Disclosure Act provides for "protected disclosures" cases involving investment banks include Bhatia v Sterlite Industries (2001) and two cases related to investment bank Nomura. For a sophisticated whistle blowing scheme, see the following text.
} 
unless actors are driven by morality, or seek to retaliate, ${ }^{47}$ whistle blowing is unlikely to happen, or at least, it is unlikely to happen early. For the same reason, regulatory proceedings ex ante have little prospect of revealing relevant agreements if the respective behavior is unlikely to be sanctioned in the future. Effectiveness of ex ante measures depends on the effectiveness of ex post enforcement.

\section{Ex post enforcement: No Market-Based Pricing}

For the most part, the above sanctions do not change the fact that the acquisition has not been priced by the market, as it would have been if the acquisition was disclosed appropriately. Enforcement does not make the takeover subject to a true market test that enables market participants to assess the consequences and the seriousness of the takeover attempt. ${ }^{48}$

If regulators let the acquisition proceed (regardless of penalties being imposed on the bidder), due to inefficient time and planning, competitors are unlikely to issue a competing bid: Instigating a potentially unsuccessful bidding war is costly. By virtue of the Equity and / or the Service Strategy the scheme participants, or the acquirer, respectively enjoy a headstart in the takeover bid. They have assembled a significant, sometimes even controlling stake at low costs. Without these stakes, taking over the issuer may turn out to be difficult. In addition, if the scheme secured a low stock price for its base stake, its overall takeover costs are lesser than those of a competing bidder even if it offers a higher price for the (remaining) outstanding shares of the target later on. If the competitor succeeds it does so by paying a significant premium from which inter alia the scheme participants / the acquirer (a competitor?) benefit.

These aspects lead to a lesser number of competing bids than is desirable, from the shareholders' perspective. Moreover, once the acquirer's stake has passed the control threshold by virtue of hidden

\footnotetext{
${ }^{47}$ The same incentives may keep participants to remain loyal to the participants, see Sydney A. Fine, Whistle Blowing and Industrial Psychology (2006) The IndustrialOrganizational Psychologist 43:3, at 21; Axelrod, The Complexity of Cooperation (NJ, Princeton UP: 1997) at 59-60.

${ }^{48}$ Admittedly, demand created from Equity and Service Strategies can be expected to support the target's share price even in the absence of disclosure.
} 
strategies, its interest in acquiring further shares may be limited. They may issue a mandatory bid at the minimum price.

If regulators decide in favor of banning the acquisition altogether, or mandating a cooling-off, they deprive shareholders of a bid altogether. Although not on fair, i.e. market-adjusted terms, any bid provides a put option to the shareholders and signals under-valuation to the market. In particular, in downward market cycles, a bid following a secret acquisition strategy may be the better option for shareholders when compared to a state in which there is no bid. ${ }^{49}$ Moreover, while there may be signaling effects and a possible transfer of proprietary information to other acquirers, if the bid is prohibited from going through, the acquirers' investment in information and financing is reduced in value, which, from a social perspective, may be wasteful.

\section{Burden of Proof}

Probably the most relevant downside of traditional enforcement is that traditional enforcement does not overcome issues associated with the burden of proof. Since documentation is scarce, regulators are doomed to speculate about the likely content of underlying agreements; speculation rarely stands a critical review in court. The difficulties with evidence have prompted commentators ${ }^{50}$ to argue in favor of a shift in the burden of proof, and some lower courts ${ }^{51}$ as well as regulators ${ }^{52}$ have followed suit.

\footnotetext{
${ }^{49}$ This was the case in the Schaeffler's bid for Continental, see Dirk A. Zetzsche, Hidden Ownership in Europe: BAFin's Decision in Schaeffler v. Continental, (2009) 10:1 EBOR 115 , at 141.

${ }^{50}$ For example, Reinhard H. Schmidt / Gerald Spindler, FINANZINVESTOREN AUS ÖKONOMISCHER UND JURISTISCHER PERSPEKTIVE (transl.: Financial investors from an economic and legal perspective) Nomos: 2008, at p. 250 \199.

${ }^{51}$ See the court of first instance in re Perry vs Ithaca, [2003] 2 NZLR 216 (Potter J), revised by Court of Appeal, New Zealand, Perry Corporation vs Ithaca (Custodians) Ltd., [2005] Part 4 Case 11 [NZCA], No. 21, 25.

${ }^{52}$ This is true for the Portuguese securities regulator CMVM in the cases of Semapa and Portugal Telecom, where the CMVM concluded from voting behavior that agreements existed. Similarly, the Italian regulator CONSOB applied such as doctrine when concluding that an implicit agreement existed in the FIAT-IFIL / EXOR case, See L.Curran and F. Turitto, 'Fiat/ Ifil: The Securities Law Implications for Equity Derivatives', 21:7 Journal of International Banking and Financial Law (JIBFL) (2006) p. 298; G. Ferrarini, Prestito Titoli e Derivati Azionari nel Governo Societario in Balzarini/Carcano/Ventoruzzo, La società per azioni oggi: Tradizione, attualità e prospettive.- Vol II (The corporation today: tradition, presence and future), (Venice,
} 
These institutions held that in certain situations prima facie evidence re the illegality of a hidden acquisition suffices for the imposition of sanctions, or mandating a cooling-off.

Shifting the burden of proof has obvious disadvantages: generally speaking, the risk is imposed on the acquirer that any conduct is deemed unlawful. Since such a scheme renders takeovers less likely, it reduces incentives for information production about under-valued issuers. As a potential response to shifting the burden of proof, bidders might reasonably elect to incur greater costs to ensure compliance with - and to be seen complying with - the relevant legal requirements. To the extent that such compliance costs increase the overall costs associated with any potential bid, they decrease the marginal likelihood that bids will develop in the first place.

Moreover, the regulators' task is assigned to the acquirers. The fact that acquirers may be deemed to be culprits (with related administrative or criminal sanctions) in the absence of evidence or defections prompts constitutional concerns. When subject to appeal, shifting the burden of proof partially or entirely to the acquirer has not withstood critical review. ${ }^{53}$

\section{A Reward Model}

If authorities fail to enforce existing rules, designing new rules does not seem to be the obvious idea. Instead, we may focus on enforcement. In particular, a reward model that overcomes said disincentives is desirable.

Giuffrè 2007), at 629 and 663 pp.; S. Bragantini, 'Se l'equity swap dribbla la comunicazione', (When equity swaps dribble the communication) (Lavoce) (25 September 2005), with the response by Gabetti (Lavoce) (25 September 2005), available at: http://www.lavoce.info. For the CONSOB decisions against Ifil (market manipulation) see Delibera (decision) n. 15760, 9 February 2007; against Exor (wrongful disclosure) see Delibera n. 16068, 1 August 2007; and against Merrill (wrongful disclosure), Delibera n. 16248, 1 December 2007, available at: http://www-consob.it. Ifil, Exor and Merrill appealed to the CONSOB decisions at the Corte D'Appello di Torino [Torino Court of Appeal]. On 5 December 2007, the sanction against Ifil was upheld, while the sanction against Exor was rejected due to a procedural problem, see Case 214/07 VG, available at: http://www.consob.it/main/documenti/decreti_ca/2007/ca_20071205_torino_IFIL.htm.

${ }^{53}$ See references supra n.s 51 and 52. 


\section{The Antitrust Analogy}

For such a model, we need to understand each participant's incentives. Once the scheme engaged in a violation of disclosure rules each participant faces two options: (1) (early) disclosure, or (2) silence. As a starting point, assuming for reasons of simplicity ${ }^{54}$ a circumventive scheme with one hidden acquisition opportunity, perfect information, two participants, no distinction between participating firms and the individuals representing them, no transactions costs and inefficient ex-post enforcement, the chart of the strategies available to each participant can be drawn as follows: ${ }^{55}$

Table 1: Incentives under Traditional Enforcement

\begin{tabular}{|l|l|l|}
\hline Participant A / B & Disclosure (B) & Silence (B) \\
\hline Disclosure (A) & $P(A)_{t 0}-F(A)^{\prime} ; P(B)_{t 0}-F(B)^{\prime}$ & $P(A)_{t 0}-F(A)^{\prime} ; P(B)_{t 0}-F(B)$ \\
\hline Silence (A) & $P(A)_{t 0}-F(A) ; P(B)_{t 0}-F(B)^{\prime}$ & $\alpha \times P(A)_{t 1} ; \alpha \times P(B)_{t 1}$ \\
\hline
\end{tabular}

$P(A ; B)$ denotes the profits made by participants $A, B$ from the stock price reaction due to disclosure at two points in time $t_{0}$ (early disclosure) and $t_{1}$ (later disclosure); $\alpha \mid[0<\alpha<1]$ denotes the probability of detection of the scheme in the future, and $F(A ; B)$ denotes any penalty ('fine') resulting from disclosure. $F$ includes administrative fines, criminal prosecution, litigation by investors that received too little when selling their shares under circumstances of inaccurate information, or costs for defence against any charges resulting from the disclosure. Early disclosure may reduce the size of $F(A ; B)$, since defection reduces the fines set by official bodies (agencies, judges) and, since fewer shareholders traded under circumstances of inaccurate disclosure, there is less potential for investor litigation. While the latter benefit is shared by all participants, only the defector benefits from the former. In turn, defectors may suffer from

\footnotetext{
${ }^{54}$ The qualifications will be turned into a real world setting in the following sections infra.

${ }^{55}$ The model will be narrowed down further down below.
} 
punishment by fellow wrongdoers in future acquisitions. In any event, the size of $\mathrm{F}$ is likely different in the state of early disclosure than in the state of silence. My model considers this aspect as $F(A ; B)$ '. This does not change the fact that any $F$ is a cost $(F>0)$.

Since ex post enforcement is inefficient (see above), i.e. $\alpha \rightarrow 1$, the size of the expected future profit at $t_{1}$ is not significantly reduced by risk considerations. As long as $P(A ; B)_{t 0}<P(A ; B)_{t 1}$, i.e. the stock price premium (announcement effect) at the time of early disclosure $\left(t_{0}\right)$ is lesser than at a later point in time $t_{1}$, there, is any $P(A ; B)_{t 0}-F(A ; B)^{\prime}<P(A ; B)_{t 1}$. Under that condition, if $A$ and $B$ remain silent, they will do simultaneously better than in the case of joint or individual disclosure.

The participants' decisions suffer from bounded rationality ${ }^{56}$ in terms of accurately forecasting the announcement effect; they cannot look into the future nor can they estimate with certainty whether there is $P(A ; B)_{\text {to }}<$ $P(A ; B)_{t 1}$. They don't need to. Rather than an objective calculus it is each participant's opinion that drives decision-making. Each participant is likely to make its personal calculus in order to determine whether it thinks that there is $P(A ; B)_{t 0}<P(A ; B)_{t 1}$. If they do, they will remain silent. Notwithstanding any leak of information which renders early disclosure by other participants likely, cooperation gets all participants to remain silent and guarantees a net profit. Even in the absence of future opportunities silence is the collusive equilibrium. In particular, participants do not face a Prisoner's Dilemma as there is no incentive to defect.

In reality, we observe $n$-person schemes. ${ }^{57}$ However, due to the binary nature of the decision, we can understand $A$ and $B$ in the model above as any sub-coalition in the group of $n$ participants that discloses the scheme or remains silent, as applicable. Example: Group A may consist of participants 1 and 2 who are willing to disclose, while $B$ represents all

\footnotetext{
${ }^{56}$ See Herbert Alexander Simon, Theories of decision making in economics and behavioural science, (1959) American Economic Review 49:3, pp. 253 - 283.

${ }^{57}$ See on $\mathrm{n}$-person schemes Roger B. Myerson, Game Theory - Analysis of Conflict (Cambridge, MA, HUP: 1997), at 417 et seq.; for a general theory of n-person games and its application to economics see John von Neumann \& Oskar Morgenstern, Theory of Games and Economic Behavior, 1944, Sixtieth Anniversary Edition 2004, Princeton and Oxford: Princeton University Press: 2004, S. 238 ff..
} 
other participants $3-\mathrm{n}$ who wish to maintain secrecy. The essential message of above model will not change.

This incentive structure is similar to the incentives of cartel participants prior to the detection of the cartel by antitrust authorities. ${ }^{58}$ Extending the principle that wrongdoers who report their misdeeds can expect less harsh punishment, ${ }^{59}$ U.S. as well as European antitrust law provides for leniency, i.e. the first antitrust violator disclosing the cartel benefits from lenient regulatory treatment. ${ }^{60}$ Leniency aims to destabilize cartels, and ultimately to detect cartels through defection. By reducing the expected fine $F(A ; B)$ for the defector, leniency disseminates distrust within the cartel: if one

${ }^{58}$ See C.R. Leslie, Antitrust Amnesty, Game Theory, and Cartel Stability, (2006) 31 Journal of Corporation Law 453; Leslie, Cartels, agency costs, and finding virtue in faithless agents, (2008) 49:5 William and Marie Law Review 1621; N. Zingales, European and American Leniency Programme: Two Models Towards Convergence? (2007) (On SSRN).

${ }^{59}$ The social desirability of this ancient principle of Criminal Law that is also vested in theology and philosophy, has been shown by, inter alia, by L. Kaplow \& S. Shavell, Optimal Law Enforcement with Self-Reporting Behavior, (1994) 102:3 Journal of Political Economy 583-606. Example of this principle include the U.S. style plea bargain and the German public attorney's discretion to cancel a criminal proceeding if there is no need for a public hearing in front of the judge.

${ }^{60}$ For the U.S. see US Department of Justice, Corporate Leniency Policy, available at http://www.justice.gov/atr/public/guidelines/0091.htm (1993) and Leniency Policy for Individuals, available at http://www.justice.gov/atr/public/quidelines/0092.htm (1993), as well as US Sentencing Commission, Guidelines Manual, online http://www.ussc.gov/2009guid/GL2009.pdf (as of 1 November 2009). Under the Antitrust Criminal Penalty Enhancement and Reform Act of 2004, Pub. L. No. 108-237, Title 2, §§ 211-214, 118 Stat. 661, 666-668, a leniency applicant may qualify for detrebling of damages if the applicant cooperates with plaintiffs in their civil actions while the applicant's former co-conspirators will remain liable for treble damages on a joint and several basis. Relevant information on US-leniency is available at the DoJ's "leniency website": http://www.justice.gov/atr/public/criminal/leniency.htm ; for Europe "2006 Commission Notice on Immunity from Fines and Reduction of Fines in Cartel Cases", 2006/C298/11, OJ C 298/17 (hereafter EU Leniency Notice), as well as the "2006 Guidelines on the method of setting fines imposed pursuant to Article 23 (2)(a) of Regulation No. 1/2003, OJ C 210/2; out of the rich body of literature see M. Bigoni, S-O.. Fridolfsson, C. Le Coq \& G. Fines Spagnolo, Leniency, Rewards and Organized Crime: Evidence from Antitrust Experiments (20/05/2008). SSE/EFI Working Paper Series in Economics and Finance No. 698. Available at SSRN: http://ssrn.com/abstract=1134725; Panizza, ZEITSCHRIFT FÜR WETTBEWERBSRECHT 2008, 58; G. Spagnolo, Leniency and Whistleblowers in Antitrust, in Bucirossi (Ed.), Handbook of Antitrust Economics, M.I.T.: 2007 (cited from Working Paper version) at 10 et seq.; Wouter P. J. Wils, Leniency in Antitrust Enforcement: Theory and Practice. (2007) World Competition: Law and Economics Review, 30:1. Available at SSRN: http://ssrn.com/abstract=939399; Wissmann/Dreyer/Witting, KARTELL- UND REGULIERUNGSBEHÖRDLICHE ERMITTLUNGEN IM UNTERNEHMEN UND RISIKOMANAGEMENT (transl.: antitrust and regulatory proceedings and risk management) (2008), Chpt. 5 and 8. For a critical assessment see M. Motta \& M. Polo, Leniency Programs and Cartel Prosecution (2003) 21:3 International Journal of Industrial Organization 347. 
cartel participant can benefit from harming others, it may as well seek certainty in the arms of the regulator rather than continuing to bear the (uncertain) risk that others participants defect. ${ }^{61}$

Both cartels and secret acquisition schemes keep price-sensitive information hidden from the markets. On a first look account, Equity and Service Strategies run an information cartel regarding major shareholdings.

A second look results in a more careful judgment. Three characteristics are peculiar for cartels: ${ }^{62}$ (1) the involvement of multiple agents; (2) within the wrongdoers, there is scope for profitable defecting, and (3) due to the illegality of the underlying activity, contracts that limit opportunism vis-à-vis the fellow cartelists cannot be enforced. Conditions (1) and (3) apply to secret acquisition schemes: at least two agents ${ }^{63}$ are likely to conspire. Condition (2) is case specific. In some cases early disclosure creates opportunity for arbitrage, in others defecting on the participants is not profitable per se, as the defector may not undercut its fellows by early disclosure combined with an early sale. However, the potential lack of condition (2) does not render drawing lessons from antitrust leniency in vain: In a state where economics do not incentivize abiding by the rules, there is an even greater need to create incentives in favor of defection as compared to a state where there is an economic incentive to defect as in the case of cartels. (Please note that it is not a precondition of a cartel that all participants profit to the same extent - one cartel participant may hold a dominating share in the market -, or that all cartel participants know all the others. Similarly, with respect to secret acquisitions, one participant may be the instigator who wants to purchase the shares from the fellow

\footnotetext{
${ }^{61}$ Traditional Whistle Blowers and Crown Witnesses find themselves in similar situations. However, while the benefit of disclosure is determined by law, in the latter cases it is somewhat blurred to what extent the parties benefit from maintaining secrecy.

${ }^{62}$ Buccirossi \& Spagnolo, Corporate Governance and Collusive Behavior, in Dale W. Collins (Ed.), Issues in Competition Law and Policy, 2007, Antitrust Section, American Bar Association, Chapter XX, sub 5.

${ }^{63}$ Equity strategy: two investors working together; Service strategy: Acquirer and core intermediary.
} 
participants after the takeover succeeded, or be the only party fully cognizant of what is going on.)

Thus, a closer look at the mechanics of antitrust leniency is warranted. For cartelists reducing fines does neither infer that defection is efficient, ${ }^{64}$ nor that defection is costless to the defector. ${ }^{65}$ Leniency is traditionally applied to organizations 1) that are intrinsically unstable because each participant has an incentive to defect even in the absence of leniency (in the case of cartels, to undercut other cartelists by offering a better, yet still profitable price to their customers), ${ }^{66}$ and 2) where traditional enforcement activities impose a significant threat on cartel participants to be detected even in the absence of defection. ${ }^{67}$ Through traditional enforcement, agencies seek to achieve a situation in which the calculus of all cartelists for silence (and, hence, an internal system of cartel discipline and punishment) includes a realistic probability that the cartel is detected, and its participants being severely punished, regardless of silence. This includes presenting some minor charges with good evidence in order to extract new evidence relating to fellow cartelists through the use of leniency.

With respect to shareholder transparency rules, 1) participants are not per se incentivized to defect (see above), and 2) there are no related minor offences that could be invoked by the agencies. Moreover, while a cartel is maintainable in the long run, ${ }^{68}$ the Equity and Service Strategy does not endlessly benefit from secrecy. While secrecy is necessary for a certain period of time in order to assemble the significant stake in the issuer, ${ }^{69}$ at

${ }^{64}$ Consider the effect of $F(A ; B)$ ' $<F(A ; B)$; under inefficient enforcement, silence remains the option where both do simultaneously best.

${ }^{65}$ Leniency reduces fines, but some fines remain. In addition, the defector bears sanctions by fellow cartelists.

${ }^{66}$ G. Stigler, A Theory of Oligopoly, (1964) 72:1 Journal of Political Economy 44-61.

${ }^{67}$ Wils (2007), supra n. 60, at 22; Wils, The Commission Notice on the Non-Imposition or Reduction of Fines in Cartel Cases: A Legal and Economic Analysis (1997) 22 European Law Review 123, at 133.

${ }^{68}$ This is why cartels are able to develop an internal sanction system, see $T$. Schelling, The Strategy of Conflict (HUP: 1960); J. Friedman, A Noncooperative Equilibrium for Supergames, (1971) 38 Review of Economic Studies 1-12.

${ }^{69}$ TCl's Service and Equity Strategy was pursued for as long as 18 months, with varying levels of disclosure resulting in approx. $18 \%$ of the target's stock. Schaeffler initiated its Service Strategy for approx. six months prior to disclose, resulting in a $36 \%$ stake. 
a certain point in time, acquirers need to go public in order to profit from their strategy: All feasibilities to increase the value of the participant's investment - the announcement premium, governance changes due to coercion by the acquirers, or strategic changes following a takeover require disclosure of the joint stake (albeit not defection). For circumventive schemes in the domain of shareholder transparency rules to be successful, the secret informational advantage must be transformed in real-world premiums.

However, when all other factors (the number of participants, the profits etc.) are equal, ${ }^{70}$ it is more likely that one wrongdoer defects the longer the scheme is run. Moreover, external effects (like other investors' complaints, technical market supervision etc.) render detection of a long-run scheme more likely than detection of a scheme run for a short period of time. The short period of time required for successfully applying the Equity or Service Strategy, in addition to the disincentives to defect, makes it particularly hard to reveal secret acquisitions schemes. Therefore, the incentives in favor of disclosure of major shareholdings have to be greater, in relative terms, when compared to antitrust leniency programs.

Since leniency, i.e. reducing fines, does not suffice for inducing disclosure in an environment in which fines are unlikely in the first place, I propose a whistleblower reward policy. ${ }^{71}$ This idea is not alien to the law: Inter alia, a reward policy was part of the very first British stock broker regulation in the

\footnotetext{
${ }^{70}$ Each participant re-calculates its chances more often and has more opportunities to defect.

${ }^{71}$ The idea is particularly promoted by antitrust theorists, see C. Aubert, P. Rey and W.E. Kovacic, The Impact of Leniency and Whistleblowing Programs on Cartels, (2006) 24 International Journal of Industrial Organisation 6; Bigoni et al. (supra n. 60), at 21; Paolo Buccirossi \& Giancarlo Spagnolo, Leniency Programs and Illegal Transactions (2006) 90:6/7 Journal of Public Economics 1281; W.E. Kovacic, Private Monitoring and Antitrust Enforcement: Paying Informants to Reveal Cartels (2001) 69 George Washington Law Review 766; Kovacic, Bounties as Inducements to Identify Cartels in C. D. Ehlermann / I. Atanasiu (eds.), European Competition Law Annual 2006: Enforcement of Prohibition of Cartels (Hart Publishing, 2007); Leslie, Cartel Stability (2006), supra n. 58, at 473 et seq.; Leslie, Faithless Agents (2008), supra n. 58, at 1664 et seq.; G. Spagnolo, Optimal Leniency Programmes, F.E.E.M. Nota die Lavoro No. 42.00 (available on SSRN); Spagnolo, Divide et Impera: Optimal Leniency Programmes, CEPR Discussion Paper No. 4840 (on SSRN); A. Riley, Beyond Leniency: Enhancing Enforcement in EC Antitrust Law" (2005) 28 World Competition 377. For a critical assessment, see Wils (2007), supra n. 60 , at 44 .
} 
$17^{\text {th }}$ century. ${ }^{72}$ Moreover, collaboration with authorities is rewarded by the U.S. False Claim Act, for employees that reveal fraud to the federal government, ${ }^{73}$ by the U.S. Department of Justice's Amnesty Plus program in antitrust ${ }^{74}$ as well as in South-Korean competition law. ${ }^{75}$ Reward policies worked well in Italy (in fighting the Mafia and Terrorism) ${ }^{76}$ and have been used for catching "wanted" criminals for centuries by offering bounties to fellow criminals as much as non-involved people. Moreover, albeit most often not a wrongdoer, one may understand the auditor, ${ }^{77}$ or the compliance officer, who is to report to independent directors, or the supervisory board, as the case may be, as person rewarded for blowing the whistle. The idea of rewards in return for disclosure is not alien to the law as a first glance suggests. New, though, is its application as enforcement measure in the context of Securities Law.

\section{Key Assumptions}

A reward policy must be carefully crafted in order to prevent exploitation as much as issues with retributive (in-)justice. In determining which premium should be assigned to the first discloser, I make three assumptions:

\footnotetext{
${ }^{72}$ See Robert R. Pennington, The Law of Investment Management, 1990, p. 29. According to Pennington, persons who carried on business as brokers without being licensed were subject to penalties which could be prompted by a common informer. The common informer was entitled to keep half of the penalty for himself.

${ }^{73}$ From a legal perspective see R.L. Howse \& R. Daniels, Rewarding Whistleblowers: Costs and Benefits of an Incentive-Based Compliance Strategy in R. Daniels \& R. Morck (eds.), Corporate Decisionmaking in Canada (Calgary: Calgary UP: 1995); from an economic perspective, see F. Koffman \& J. Lawaree, A Prisoner's Dilemma Collusion Deterrence, (1996) 59 Journal of Public Economics 117-136; D. Robert Cooter \& Nuno Garoupa, The Virtuous Circle of Distrust: A Mechanism to Deter Bribes And Other Cooperative Crimes, (2000) Berkeley Olin Program in Law \& Economics, WPS 1057. From the sociological perspective see M.P. Glazer / P. Glazer, The Whistleblowers: Exposing Corruption in Government and Industry, (NYC, Basic Books: 1991); F.C. Alford, Whistleblowers (Ithaca, Cornell UP: 2002).

${ }^{74}$ Amnesty plus offers cartelists, in case they reveal a second
involved with but about which the DoJ was not aware, a subs
due for the first cartel for which they were convicted. Appare
successful, see S.D. Hammond, "An Overview Of Recent Deve
Division's Criminal Enforcement Program," (2005), available
${ }^{75}$ Wils (2007), supra n. 60 , at 46 (for non-participants only).
${ }^{76}$ G. Spagnolo (2007), supra n. 59 , at 7.
${ }^{77}$ Buccirossi \& Spagnolo, Leniency Programs, supra n. 71.
} 
First, I assume that there is no hard evidence regarding the specific violation of disclosure rules that dawn raids and other ex-post devices may unmantle. Whether regulatory pressure is successful primarily depends on one participant defecting by admitting the existence of the scheme to regulators, or by publicly disclosing the major shareholding earlier than other wrongdoers expected. The relatively few cases in which backwardoriented regulatory diligence resulted in regulatory sanctions, provide a factual foundation for this assumption.

Secondly, I assume that the longer the acquisition strategy remains undisclosed, the larger the proportion of the target's share the participants can assemble without the market noticing is.

Third, I assume that stock prices will respond to first time disclosure of major shareholdings by abnormal returns. I disregard any price adjustment resulting from the strategic or industrial logic of the takeover. While studies show significant abnormal returns in case of disclosure of hedge fund activity, ${ }^{78}$ it is unclear what prompts these effects, given that the same studies show significant abnormal losses one year following these disclosures. One would expect markets to anticipate these long term losses and even out abnormal returns, in the first place. For the purposes of this model, this riddle is willfully disregarded. ${ }^{79}$

In order to reveal the impact of the reward policy, I will go on to define the Premium (E.III.) and analyze its impact on the Equity Strategy (E.IV.) and the Service Strategy (E.V.) separately.

\section{Defining the Premium}

Given that all participants invest in the target's shares, the joint holding of the group exceeds the holding of each participant. If there is a significant stock price reaction upon announcement of the major shareholding, each participant benefits from the Announcement Premium to the same extent as it holds shares in the issuer. The group's collective profits are greater than each of the participant's profits; they are the sum of each participant's

\footnotetext{
${ }^{78}$ Supra n. 16.

${ }^{79}$ For qualifications see infra E.
} 
profits. $^{80}$ I suggest that law assigns the Announcement Premium on the shares held by the group to the first participant ${ }^{81}$ disclosing the scheme to the market. I refer to the discloser's claim stemming from this legal distribution of cash-flows as 'Premium Claim' ('PC').

Example: Wrongdoers A (holding 1\%) and B (holding 4\%) hold jointly a $5 \%$ stake in target T. Upon A's early disclosure (deflection), T's market capitalization jumps from 5 Bio. to 6 Bio. A is granted a Premium Claim worth $5 \%$ of 1 Bio. against B, i.e. 50 Mio. The Premium Claim is reduced by A's own share in the overall stake (i.e. 10 Mio.) leaving him with B's profits made upon announcement (40 Mio.). In addition, A enjoys leniency with respect to administrative penalties and is excluded as target of investor suits for wrongful disclosure. ${ }^{82}$

The Premium Claim reflects the information value related to disclosure of the major shareholding. If the market does not respond to disclosure, foregoing disclosure will not harm anyone; in this case, disclosure is not a valuable service to the market that warrants reimbursement. If the market, in fact, responds to disclosure - the fact that all parties have refrained from disclosure up to defection indicates that all participants (prior to disclosure) came to the conclusion that $\mathrm{P}(\mathrm{A} ; \mathrm{B})_{\mathrm{t} 0}<\mathrm{P}(\mathrm{A} ; \mathrm{B})_{\mathrm{t} 1}{ }^{83}-$ the Premium Claim deprives the loyal participants of their benefits from secrecy. The remaining participants forego the abnormal returns associated with the Announcement Premium. In terms of return, the participants are back to the start. In the aftermath of such disclosure, traditional enforcement is likely to be more effective, since the defector provides enforcement agencies with good information. Litigation by

\footnotetext{
${ }^{80}$ Let AP describe the announcement effect, $p$ (i) the individual participant's share in the issuer, and $p(g)$ the group's share. If $p(g)>p(i)$, then [AP $\times p(g)]>$ ]AP $\times p(i)]$.

${ }^{81}$ The term participant refers to any legal entity / firm (corporation, fund, bank) involved in the Equity Strategy or the Service Strategy.

${ }^{82}$ The US antitrust leniency programs require the defector to provide restitution to harmed consumers. A restitution requirement offsets to a certain extent the pro-defecting incentives from leniency. In the context of antitrust, due to the natural instability of cartels, such a treatment may be justified. There is no equivalent instability in the context of secret acquisition schemes. Similarly, a minor, but automatic administrative fine may be acceptable and feasible, but it reduces the incentives to disclose set by the Premium Claim.

${ }^{83}$ See supra D.I.
} 
investors that sold their shares at the wrong price and administrative sanctions may impose further costs on the non-defecting participants; regulators may require, ban or stand-by a takeover bid as the case may be.

A look at the incentive structure based on the same conditions as Table 1 (supra) reveals the impact of the Premium Claim on the scheme. Let PC be the Premium Claim, as defined above, and $P C(A ; B)$ be the fraction of the Premium Claim which $A$ or $B$ have to pay to the defector upon early disclosure. Under the reward model, the alternative strategies look like:

Table 2: Incentives under Reward Policy

\begin{tabular}{|l|l|l|}
\hline Participant A / B & Disclosure (B) & Silence (B) \\
\hline Disclosure (A) & $P(A)_{t 0}-F(A)^{\prime} ; P(B)_{t 0}-F(B)^{\prime}$ & $P C ; P(B)_{t 0}-F(B)-P C(A)$ \\
\hline Silence (A) & $P(A)_{t 0}-F(A)-P C(A) ; P C$ & $\alpha \times P(A)_{t 1} ; \alpha \times P(B)_{t 1}$ \\
\hline
\end{tabular}

Since the Premium Claim is defined as the announcement effect on the joint-stake of participants $1-n$, while $A$ or $B$ may only profit in proportion of their own fraction of the scheme which is $P(A ; B)$, and $0<\alpha<1$, there is any $\alpha \times P(A ; B)_{t 1}<P C$. If the Premium Claim is assigned to the first defector, remaining silent does not provide for $A$ and $B$ simultaneously the best solution: It is impossible to maximize the value of two (or more) independent ${ }^{84}$ functions at the same time..$^{85}$ Instead, the only way for both participants simultaneously to make a profit is if both disclose jointly and simultaneously, given that for each $A$ and $B P_{t 0}>F^{\prime}$. The logical consequence for $A$ and $B$ is to collude - by joint disclosure. If $A$ and $B$ each independently - come to the conclusion that they have to disclose anyway, as otherwise they will not profit from the scheme, they may as

\footnotetext{
${ }^{84}$ That is: $f(A) \neq z \times f(B)$.

${ }^{85}$ See John von Neumann \& Oskar Morgenstern, Theory of Games and Economic Behavior, 1944, Sixtieth Anniversary Edition 2004, Princeton and Oxford: Princeton University Press: 2004, S. 10 f. (obviously, it is possible to determine the greatest joint value).
} 
well make sure that $F$ is as small as possible. This means: they disclose as late as possible, as long as $F=0$. In other words, $A$ and $B$ would agree on disclosure in accordance with disclosure rules. This is exactly what we want them to do.

\section{The Equity Strategy}

The incentive structure provided in the previous sections relied on the premise of a one-sequence-setting, i.e. the participants do not see each other again after they decided to cash in the Premium Claim. In the real world, this condition may not hold. Given this further complexity, how does the Premium Claim impact on the Equity Strategy?

\section{Expected Future Pay-Off}

For the Equity Strategy, the Premium Claim creates an Iterated Prisoner's Dilemma ${ }^{86}$ among the participants, with two qualifications: (1) participants know ex ante that they will be placed in this dilemma, and (2) participants can communicate. ${ }^{87}$ Robert J. Aumann has shown that rational actors determine their strategy (cooperation, deflection) with regard to the discounted value of the future payoff of each strategy. ${ }^{88}$ Participants seek to assess, in light of the significant uncertainty regarding future stock price developments and other participants' incentives and (irrational?) motives, which risk scenario (disclosure / non-disclosure) if adjusted to risk, results in the greatest payoff.

The holdings of Scheme 1 will be disclosed if the sum of the risk-adjusted discounted value of the Premium Claim [PC] minus transaction costs (for example, legal advice, litigation) [TC] minus the sum of the risk-adjusted discounted future profits $[\mathrm{P}]$ from all cooperative schemes $2-n$ where

\footnotetext{
${ }^{86}$ Please note that in the absence of a reward scheme there is not a prisoner's dilemma since, in most cases, there is no economic incentive to defect.

${ }^{87}$ For potential consequences of these qualifications see infra D. IV.4.

${ }^{88}$ See Robert J. Aumann, Acceptable Points in General Cooperative n-Person Games, in H.W. Kuhn and R.D. Luce (eds.), CONTRIBUTIONS TO THE THEORY OF GAMES IV, Princeton, PUP: 1959, at 287 et seq*; Aumann, Repeated Games with Incomplete Information (1995)* and Collected Papers - Vol. 1 (2000), at *.
} 
participation and payoffs depend on whether the participant defected in Scheme $1,{ }^{89}$ is greater than Zero. ${ }^{90}$

Fig 4: Premium Claim vs. Expected Future Cash-Flows from Cooperation

$$
\mathrm{PC}_{1}-\mathrm{TC}_{1}-\sum\left(\mathrm{P}_{2-n}\right)>0
$$

It is reasonable to assume that $\mathrm{TC}_{1}$ is low, in relative terms, if the defector acts according to the law. Whether the Premium Claim results in disclosure depends for the most part on the expected future pay-off from projects in which the defector cannot cooperate since it is excluded from participation due to its defection at this project. $^{91}$

An ideal model would provide an equilibrium under which no participant is interested in the scheme's collective stake in the target surpassing a disclosure threshold without disclosure, for fear of defection by other participants that seek to capitalize on the Premium Claim. However, as long as the participants assume that (1) the size of the Premium Claim correlates with the size of the joint shareholding of all participants, and (2) all (other) participants stay honest, any potential defector in the team has reasons to maintain the strategy rather than disclose.

\section{Correlation of Premium Claim with joint shareholding}

The first assumption - i.e. that the announcement premium is greater, the more shares the participants assemble - holds water in the low digit range. Upon disclosure, the greater joint share of the participants signals greater commitment which in turn signals a more significant underevaluation of the target's stock. This assumption may not hold if the joint

\footnotetext{
${ }^{89}$ Retaliation is likely as the individuals involved have memories (while markets do not). For cartels see Zingales, supra n. 58, at 26. Exclusion is the most likely type of retaliation in the sphere of finance. Alternatively, investors could lure the defector in a trap, by setting up a scheme designed to recuperate the losses from Scheme 1 in a set-up Scheme 2.

${ }^{90}$ My model disregards the costs of financing the said project. Given the short period of time required for the scheme itself to work, the time value of money plays a minor role for the assessment.

${ }^{91}$ The incentives diverge if the Premium Claim is granted to individuals (agents, employees) rather than the participants. See infra D.V.3.
} 
share comes close to or even reaches de facto control. ${ }^{92}$ After de facto control has changed hands, two key drivers of the stock price, defensive measures and a competing bid, are unlikely from the outset. Further stock price reactions may, however, stem from legal requirements, such as the mandatory bid rule or specific investor protection schemes. ${ }^{93}$ Please note that secrecy beyond de facto control is rare; disclosure of de facto control is necessary for exercising control. If the participants' joint stake is that large, regulatory scrutiny (albeit unsuccessful) will increase transaction costs. Moreover, in some cases, disclosure of new de facto control may reduce the stock price, since it ends speculation about possible acquirers.

\section{Infinite Secret Acquisitions Game}

If in the low digit range the Premium Claim grows by waiting, any potential defector's further hesitation to disclose depends on the second assumption that other participants do not defect. As was pointed out above, whether the Premium Claim results in disclosure in an infinite setting depends for the most part on the expected future pay-off of projects from which the defector is excluded.

It is helpful for the reward model that future pay-offs count less than present pay-offs, because the individuals involved do not know whether another opportunity will come up where avoiding disclosure rules results in profits. The future pay-off is only a fraction of the present. ${ }^{94}$

Example: Let $d$ (discount parameter) describe the discount relative to the previous move. If there is $d=1 / 2$, i.e. a $50 \%$ chance to meet again, the loss from early disclosure would comprise of one full loss (1) for the current project $\left(p_{1}\right)$, only $50 \%$ for $p_{2}(1 / 2), 25 \%$ for $p_{3}(1 / 4)$ and so on $(1 / 8 ; 1 / 16$; $1 / 32$ etc.). If all future projects resulted in the same profit, the cumulative

\footnotetext{
${ }^{92}$ Please note that I distinguish between de facto control, which is the ability to decide corporate matters depending on shareholder votes, and legal control, which prompts the mandatory bid under Article 5 of the Takeover Directive (supra n. 28).

${ }^{93}$ Examples include the Evaluation Proceeding ('Spruchverfahren') where in the aftermath of corporate transactions, the consideration for minority shareholders is review by the courts.

${ }^{94}$ See Martin Shubik, Game Theory, Behavior, and the Paradox of Prisoner's Dilemma: Three Solutions, (1970) Journal of Conflict Resolution 14: 181-194.
} 
value of the sequence is $2 \times \mathrm{p}_{1} .{ }^{95}$ Under that condition, defectors would forego only the double profits of participation in the current project. In the absence of transaction costs, defection would be likely if $P C<2 p_{1}$. Under these conditions ( $50 \%$ chance to meet again, same profit as $\left.p_{1}\right)$, one more participant needs to hold a stake of the same, or a larger, size as the defector in order to make disclosure a profitable strategy. A $90 \%$ chance to meet again would require a reward 10 times the current profits, while for a $10 \%$ chance any reward greater than the profit incentivizes disclosure. ${ }^{96}$ However, neither the first model assumption that participants calculate the probability to meet again nor the second that all future projects result in the same profit ${ }^{97}$ can be transferred in the real world. In reality, there is significant uncertainty both with respect to the 'if' (chance to meet again) and the 'how' (expected profits) of future opportunities.

Responding to this uncertainty, wrongdoers may apply TIT-FOR-TAT, i.e. a strategy which cooperates on the first move and then does whatever the other player did on the previous move. ${ }^{98}$ According to that pattern, in a perennial game with uncertain information, as long no one else defects, we would expect no participant to defect either, as TIT-FOR-TAT results,

\footnotetext{
${ }^{95}$ The definite value of the infinite sequence $S(1 / 2 ; 1 / 4 ; 1 / 8$, etc.) is 1 , since $S$ is a geometric series i.e. a series where each term is $r$ times the previous term. For geometric series if the first term is $x$, the value $(\mathrm{V})$ of $S$ is: $V=x+x r+x r^{\wedge} 2+x r^{\wedge} 3+x r^{\wedge} 4$, etc. $V(S)$ can be calculated by multiplying the equation by $r$ and subtracting the second equation from the first equation. That is: $V-r V=x=>V=x /(1-r)$. Economists use geometric series in order to calculate the present value of a steady stream of cash flows.

In the example, there is $x=1 / 2$ and $r=1 / 2$. $\Rightarrow$ (1) $V=0.5(1-0.5)$; (2) $V=0.5 / 0.5=1$.

${ }^{96}$ A changing probability impacts on the outcome, as the cumulative value is $\sum\left(1+d^{2}+\right.$ $\left.d^{3}+d^{4} \ldots .+d^{n}\right)$, or $1 /(1-d)$. Please note that $d$ (as probability) is less than one and the minimum foregone profit is the expected profit from the current project.

${ }^{97}$ There are no obvious probabilities for the future course of stock markets. In terms of Game Theory, the course is a "subjective unknown". See Myerson (supra n. 57), at 6.

${ }^{98}$ This simple pattern by Anatol Rapoport of the University of Toronto performed best in the two-person, zero-sum, infinitely Iterated Prisoner Dilemma that was the basis for Axelrod's experiment on whether, and which type of, cooperation would turn out to pay off. Axelrod drew far-reaching conclusions from this result to the real world, see Robert Axelrod, The Evolution of Cooperation (NYC, Basic Books: 1984, revised ed. 2006), at 54: "What accounts for TIT-FOR-TAT's robust success is its combination of being nice, retaliatory, forgiving, and clear. Its niceness prevents it from getting into unnecessary trouble. Its retaliation discourages the other side from persisting whenever defection is tried. Its forgiveness helps restore mutual cooperation. And its clarity makes it intelligible to the other player, thereby eliciting long-term cooperation." TIT-FOR-TAT does not work in an n-person setting, see Axelrod, supra n. 47, at 44.
} 
from an overall perspective, in the best outcome. ${ }^{99}$ However, activist hedge funds ${ }^{100}$ or private equity funds - these are the entities engaged in the Equity Strategy - are not perennial players. These entities are set up for a limited period of time, due to tax reasons, and interested in increasing the overall success of the fund as this is the determinative figure for the manager's carried interest. ${ }^{101}$ While some fund managers seek to continue their career as fund managers, or run more than one fund - these managers have reason to invest in a reputation as an honest player in the secret acquisition game ${ }^{-102}$, other funds do not belong to a fund family; in addition, many of these funds are short-lived. ${ }^{103}$ The managers of these funds find themselves under significant pressure. Bad performance may prompt investors to request redemption of their shares. At the same time, taking home a safe albeit large extraordinary return enhances the manager's carried interest. These fund managers may prefer the safe bet of early disclosure over loyalty vis-à-vis the other participants by maintaining secrecy. This is particularly true since loyalty may come along with regulatory risks if one of the other participants gives in to the incentives provided by the Premium Claim.

Consequently, whether disclosure will happen or not, is highly casespecific, along the following lines:

\footnotetext{
${ }^{99}$ Axelrod, supra n. 98, p. 12.

${ }^{100}$ A mere $3 \%$ of hedge funds pursue an activist strategy.

${ }^{101}$ Carried interest refers to a share of profits granted to the general partners of private funds as compensation, despite not contributing any initial funds. See Timothy Spangler, A Practitioner's Guide to Alternative Investment Funds (City \& Financial Publishing, London: 2005), at 175 et seq.

${ }^{102}$ Defecting is more costly for the reputed player than for the non-reputed player, since a reputed player that defects reduces the discounted future cash-flows based on that reputation which prompts other to ask it to participate in the scheme. Anticipating this, the other participants adjust the risk factor relating to defecting by the reputed participant in their calculations accordingly, increasing their returns. This may result in stable schemes including reputed players only. In such a scheme, no one is likely to defect as long as the expected future payoffs from their honest reputation exceed the sum of the Announcement Claim minus transaction costs from each individual scheme. However, if the Announcement Premium is very large (for example, the scheme is designed to build up a significant position in a very large issuer) or one of the managers finds himself in an end-game situation, the risk-adjusted future payoffs may be lesser than large payoffs provided by the Announcement Premium. In this case, there will be disclosure.
}

${ }^{103}$ Data on fund insolvency* [tbc], 
(1) Participants with a greater share in the scheme are more likely to remain honest than participants with a minor share in the scheme, in relative terms. $^{104}$

(2) The risk of defecting increases in correlation with the number of parties involved. ${ }^{105}$ Since each of the participants' maximum share is limited by the respective disclosure rules, limiting the number of participants reduces the size of the participants' joint share in the issuer prior to disclosure.

(3) Participants with a reputation for being loyal wrongdoers, based on previous schemes, are more likely to stay honest. In the absence of extortion by fellow participants (see infra), loyalty depends on the likelihood to be involved in future schemes. The last qualification is important due to the destabilizing effect of "last games". Since all participants assume the last gamers' incentives to defect (since the cashflows from expected future projects are Zero, any reward greater than one's own fraction of profits from the current scheme results in disclosure), they do not ask last gamers ${ }^{106}$ to participate. Thus, in the second last game the fund is incentivized to defecting. This, again, will be anticipated by the others, and so on. Potential participants meeting that test may be replaced by participants of an investment fund family who either have incentives to establish a reputation, or are run by the same managers as the investment funds with said reputation. In practice, however, who is a last gamer is not obvious. Moreover, while the participants may not be last

\footnotetext{
${ }^{104}$ Assume two participants $\mathrm{L}$ and $\mathrm{S}$, assume further that $\mathrm{Sh}(\mathrm{L})$ describes the greater share, $\operatorname{Sh}(\mathrm{S})$ the smaller share in the scheme, Sh(all) the overall share and that $\operatorname{Sh}($ all) $>$ $\mathrm{Sh}(\mathrm{L})>\mathrm{Sh}(\mathrm{S})$ and that $\mathrm{SH}(\mathrm{L})+\mathrm{Sh}(\mathrm{S})=\mathrm{Sh}($ all $)$. ANN refers to the relative increase of the issuer's shares upon announcement. The Announcement Premium (AP) of the joint holding is $A N N \times \operatorname{Sh}($ all $)=A N N \times S h(L)+A N N \times S h(M)$. The relative gain of $S h(L)$ by defecting is smaller than the relative gain of $\mathrm{Sh}(\mathrm{S})$.

${ }^{105}$ If $\mathrm{B}$ is the benefit from violating the law and in order to violate the law you need $\mathrm{N}$ people to cooperate, and $\mathrm{P}$ is the cost (penalty) for each cooperating party, it would be rational to cooperate only if $\mathrm{B} / \mathrm{N}>\mathrm{P}$; as $\mathrm{N}$ grows the utility from cooperation shrinks, rendering defection more likely.

${ }^{106}$ In practice, what is a last gamer may be considered in light of the individuals involved. In particular, fellow participants may consider whether the leading agents (the managers) of the fund are likely to continue their fund manager careers.
} 
gamers, its managers may be for reasons unrelated to the scheme. ${ }^{107}$ Both aspects destabilize the collusion.

(4) Enforcing the Premium Claim in court (this is part of the disclosing entity's assumed transaction costs, see above) requires substantive details on the scheme. Participants with better information about the other participants' acquisitions are more likely to disclose the scheme than participants not familiar with the details. The participant with the best information is the organizer of the scheme. Unless the instigator is excluded from the rewards (see infra), participants will respond by limiting the information provided to the organizer. This renders coordination of the scheme harder and increases the likelihood that the coordinated efforts fail. A greater probability of failure may induce participants to disclose for capitalizing on the Premium Claim.

(5) In reality, participants use leverage. Debt provides for an incentive to run the risk of non-disclosure because the debtor may gamble and default, or file for insolvency, respectively, if one participant defects. If it does, it gambles at creditors' cost. However, as the conditions of the reward system are transparent and certain, fellow participants and lenders alike assume the agency issues associated with debt. Wrongdoers may avoid highly leveraged participants for the very reason that highly leveraged participants may impose the Premium Claim on them without corresponding threat on their own. Lenders either 1) require a higher level of security (which renders secret acquisition schemes more expensive), 2) include disclosure of the scheme's overall stake as a covenant of the debt contract (which renders secret acquisition schemes less likely), or 3) require all participants to deposit the scheme's shares somewhere under its supervision, or the supervision of banks where the confidentiality requirements are lifted, together with a proxy to disclose the stakes if they exceed disclosure thresholds. In all of these cases, we may expect the quality of disclosure to improve. In the context of the Premium Claim, debt

\footnotetext{
${ }^{107}$ Example: the fund's General Partner is split in parts due to personal reasons among its shareholders.
} 
initiates private enforcement by market institutions. This is an desirable outcome.

\section{Bonding}

It was conveyed that the scheme participants find themselves in a Prisoner's Dilemma situation, albeit they (1) know ex ante that they will be placed in this dilemma, and (2) participants can communicate.

As a likely response, participants might seek to strengthen the ties among them and circumvent the requirements through further collusion. For example, the scheme coordinator may require other participants to provide security prior to being accepted as a participant. The law may render these counter-measures un-effective at low costs (for example, by declaring the underlying deposit agreement void). In any event, the reward model increases transaction costs for participants of an Equity Strategy, making it less profitable to violate disclosure rules than in the present state of inefficient enforcement.

Another likely response is extortion. As a natural consequence of previous cooperation, wrongdoers inevitably end up having information on each others' misbehavior that could be reported to law enforcers. ${ }^{108}$ Participants are likely to rely on those fellows about whom they have the best information on previous misdeeds. While the threat is not always credible - often, due to its involvement in said violation of rules, the extorting entity will bite in its own hand -, the law may respond by providing leniency (not rewards!) for complete reporting of previous violations, in addition to reporting the current one.

\section{The Service Strategy}

Transferring the results for the Equity Strategy to the Service Strategy requires some qualifications.

\section{Originator Unlikely to Disclose}

The (industrial) originator of the Service Strategy does not experience the same incentives in favor of disclosure under the Service Strategy as equity

108 Spagnolo (2007), supra n. 59 , at 4. 
investors in the Equity Strategy. Through derivative contracts, the investor has availed himself of the benefits from any return stemming from the shares that are held by the other shareholders (i.e. financial intermediaries) as hedges. A stock price increase by 1 leads to an investor's return of $1 \mathrm{x}$ the number of underlying shares for the derivative contracts lesser transaction costs. The reward model developed here does not incentivize the originator in favor of disclosure.

\section{Financial Intermediaries: Premium to Corporate Entity}

From the intermediaries' perspective, an efficient incentive-based model for the Service Strategy must consider a number of additional factors.

\section{a) Perennial Players}

While one bank may seek to harm competitors by demanding the Premium Claim, in order to raise (future) rivals' costs, ${ }^{109}$ we may assume that the other banks anticipate this option and avoid participation in the first place. However, the banks' most important asset is their reputation (In this regard, banks' incentive diverge from the incentives of the individuals who represent them, see infra D.V.3.). Although banks seem to make profits by betting against their clients from time to time, ${ }^{110}$ banks are unlikely to defect as defection may cost clients in future acquisitions. From a game theory perspective, the banks are the equivalent of perennial players. In the absence of enforcement actions, these entities are unlikely to defect. The situation essentially changes when enforcement comes into play. In order to make further profits these entities must preserve their license for providing financial services. Since the reward policy comes along with leniency by enforcement agencies, banks may defect - at the latest point in time possible.

\footnotetext{
${ }^{109}$ In the current environment of the financial crisis, this consequence is less desirable as compared to a state of healthy financial institutions. For similar effects in the antitrust domain, see C. Ellis \& W. Wilson, Cartels, Price-Fixing, and Corporate Leniency Policy: What Doesn't Kill Us Makes Us Stronger, manuscript, University of Oregon (2002).

${ }^{110}$ See Joshua Getzler, "ASIC v Citigroup: Bankers' conflict of interest and the contractual exclusion of fiduciary duties", (2007) 2 Journal of Equity 62, with further references.
} 


\section{b) Information Asymmetry}

As was pointed out above, the person most likely to disclose the scheme may be the scheme organizer due to informational advantages. This may be true for the core intermediary coordinating the multiple derivative contracts and hedging relationship. In fact, if there is a coordinator, only the coordinating bank may be in the position to defect on the acquirer by disclosing the scheme effectively. However, the core intermediary suffers from disincentives to disclose. These disincentives are likely to be particularly severe since the fees associated with large-scale derivative schemes will be greater than the fees for minor hedging activity. Moreover, the core intermediary benefits the most from a client-oriented reputation in the banking market following a successful takeover attempt.

\section{c) Taking Hostages}

To a certain extent, the acquirer may hold the banks hostage if the acquirer alone is entitled to terminate the derivative contracts through which the acquirer holds its position in the target. ${ }^{111}$ If the acquirer has assembled a large number of shares indirectly through the use of derivatives, its counterparties, or their counterparties, sit on a large portfolio of the target's shares, while their economic exposure is Zero (and should remain Zero) due to hedging. If the acquirer terminates all of the derivative agreements simultaneously (which may happen in the case of early disclosure), the banks are suddenly exposed to risk from the underlying shares. At the same time, a large fraction of the overall number of shares may be put on the market, meaning the banks may accrue losses.

Banks may protect themselves up front, by limiting the acquirer's capabilities to harm their interests. For example, when negotiating the swap, they may ask for a minimum period of time before the swap contract expires after termination, or ask the acquirer for security in order to insure against an early termination of the swap. In addition, the law may respond

111 Such a one-sided termination right was, for example, disclosed in the documents on Schaeffler's bid for Continental, see Zetzsche, Hidden Ownership in Europe: BAFin's Decision in Schaeffler v. Continental, (2009) 10:1 EBOR) 115, at 123, 131, 138. 
by adding a mandatory minimum period of time for terminating the derivative contracts, and an extraordinary termination right for the discloser vis-à-vis its counterparties, as the case may require for freeing the intermediaries from the pressure imposed on them. However, an extraordinary termination right would expose intermediaries who are part of the hedging chain that are not involved in the Service Strategy to the risks of the transaction. Setting a minimum termination period would be equally arbitrary. An extraordinary termination right or a minimum termination period is not desirable. Banks are asked to take care of themselves.

\section{Premium to Individuals (Agents, Employees)}

If defection by financial intermediaries is unlikely regardless of the Premium Claim, we may create incentives pro disclosure by granting the Premium Claim to the intermediaries' agents. Thereby, we decouple the principal's from the agent's interest. ${ }^{112}$ Rewarding the employees creates strong incentives in favor of disclosure because individuals are unable to play perennially due to a limited work- and lifespan.

Granting the premium to the participant rather than individuals is likely to work particularly well in the fund world, since the carried interest ${ }^{113}$ compensation scheme that is widely spread in the fund universe provides a similar, yet less direct personal incentive. If rewards are granted to agents or participants (funds, banks, industrial conglomerates, whatsoever), a fund manager or CEO may nevertheless decide to defect on behalf of the fund or the corporation in order to avoid liability vis-à-vis the fund investors, or the shareholders, respectively. ${ }^{114}$

The situation is different on the side of intermediaries. Confidentiality and compliance requirements as well as insider trading rules prevent

\footnotetext{
${ }^{112}$ See for antitrust Leslie, Faithless Agents (2008), supra n. 58, at 1690 et seq.; Aubert, Kovacic and Rey, supra n. 71.

${ }^{113}$ Supra n. 101.

${ }^{114}$ Legal grounds include having infringed securities laws in the first place, or for capturing corporate opportunities.
} 
employees from entering into arbitrage. ${ }^{115}$ They do capitalize on their superior knowledge only by virtue of their wages and annual bonuses. ${ }^{116}$ The law may provide a lawful path to fully capitalize on it; we may think of this mechanism as arbitrage by virtue of law. For that purpose, the law needs to lift fiduciary relationships vis-à-vis the employing bank, similar to existing whistle blowing provisions, etc.

Adjusting the calculus (Fig 4, supra) to defection by the agent rather than the participant, the holdings of Scheme 1 will be disclosed if the sum of the risk-adjusted discounted value of the Premium Claim [PC] minus transaction costs [TC] (for example, legal fees for defending claims for infringing the labor contract, litigation in order to secure PC) minus the sum of non-financial personal penalties due to the agent's defection [NF] minus the sum of the risk-adjusted discounted future income [LI] ('life income') from all work opportunities which do not materialize because the agent disclosed the schemes to regulators, is greater than Zero. ${ }^{117}$

Fig 5: Defection by Agent

$$
\mathrm{PC}_{1}-\mathrm{TC}_{1}-\Sigma\left(\mathrm{NF}_{1}\right)-\Sigma(\mathrm{LI})>0
$$

Again, $\mathrm{TC}_{1}$ is likely low, in relative terms, if the defector acts according to the law. The non-financial penalties might be significant, but cannot be calculated with certainty. In particular, a reputational loss among potential wrongdoers might be outweighed by a gain among honest people. Albeit there are likely switching costs, as the fact that the agent worked for wrongdoers renders it likely that its social environment is benevolent of people infringing shareholder transparency laws, or securities laws, in general. Regardless of the immediate pain associated with switching ones

\footnotetext{
${ }^{115}$ Even if they could, financial and legal limitations on arbitrage were likely to hamper efficient arbitrage of bank employees, see Michael C. Jensen, Arbitrage, Information Theft, and Insider Trading, in New Palgrave Dictionary of Money and Finance, London, 1992 (on SSRN)

${ }^{116}$ The latter are likely to be lower in the future as compared to the past. This may further incentivize legal and discourage illegal schemes.

${ }^{117}$ My model disregards the costs of financing the said project. Given the short period of time required for the scheme itself to work, the time value of money plays a minor role for the assessment.
} 
social environment, the sum of lost life income is the factor that will be most eminent in the agent's calculus. As agents are risk averse, they will assume the worst - non employment. If the Premium Claim enables early retirement, defection is likely to happen. Lower ranks, employees close to retirement or those who expect being ousted anyway are the most likeliest to defect. If the Premium Claim is really high, it outweighs these differences. In this case, rewards to individuals may provide the prodisclosure incentive that rewards to banks do not achieve due to the perennial play. ${ }^{118}$

Rewarding individuals renders the bank's prospect of liability the same as those of participants in the Equity Strategy: If banks cannot trust their employees, and minor leaking may result in major liability, the expected future return of providing hidden acquisition services is uncertain while significant penalties are probable. Banks and other market intermediaries are particularly sensitive to potential liability, given that their profit from an individual transaction is small relative to the profit of the investor. It is even more likely that banks refrain from participation in Service Strategies than investors in the Equity Strategy. The same applies to other (non-bank) financial firmes ${ }^{119}$ acting as core-intermediaries. If there are no banks providing these services, the secret influence on voting rights by virtue of the Service Strategy is likely to vanish. This is what we seek to achieve.

\section{E. Facing the Real World}

Applying the incentive-based enforcement model to the real world necessitates further specifications.

\section{Anticipating Early Disclosure}

One of my model assumptions is that disclosure of major shareholdings prompts significant abnormal returns. As was previously pointed out, it is uncertain what prompts these returns. If these returns reflect potential increases stemming from investor activism, or a future voluntary bid for the

\footnotetext{
${ }^{118}$ Admittedly, the individual may have limited knowledge and legal capacity to enforce its reward. The law may respond to the former by granting only a fraction (let's say $25 \%$ to $50 \%$ ) of the claim if the defection is not backed with good evidence, and to the latter by requiring regulators to assist the civil enforcement of the claim (see below).

${ }^{119}$ Hedge funds sometimes do.
} 
remaining shares of the issuer, the market may anticipate that disclosure is prompted by the Premium Claim. Whether activism or the voluntary bid will follow is uncertain. Anticipation would reduce the size of the Premium Claim, if not fully erase it. In the absence of a significant Premium Claim, the prospect of capitalizing on the Premium Claim does not induce disclosure.

Other explanations may still hold water: If assembling of a major shareholding signals an under-evaluation detected by the participants, abnormal returns may remain. The same is true if the Announcement Premium reflects expectations relating to reduced management agency costs that are the result of better shareholder monitoring by the new blockholders. ${ }^{120}$ Given that there is uncertainty as to whether the Premium Claim reduces the incentives for the participants to a point where continuing the strategy is not profitable, if noise traders (i.e. uninformed investors) prompt the abnormal returns, these traders may continue to respond to disclosure. The same is true if the law requires a mandatory bid for all outstanding shares.

Assuming that the defector discloses the shareholding and, if applicable, the participants' original intentions relating to the issuer or its shares, ${ }^{121}$ (while hiding the fact that other participants are opposed to disclosure), the market may assess the information value of this disclosure. Fellow participants may feel inclined to issue an announcement to the contrary. Whether they are well-advised to issue an announcement to the contrary, however, requires careful consideration of the evidence available to the defector. Traditional enforcement punishes wrongdoers covering up their misdeeds more severely than wrongdoers admitting and correcting their crimes. Furthermore, certain sanctions such as forfeiture of shareholder

\footnotetext{
${ }^{120}$ The empirical data cited supra n. 16 carry all of these arguments.

${ }^{121}$ These requirements exist in France and Germany upon passing a certain threshold. See s. 27a of the German Securities Trading Law ('Wertpapierhandelsgesetz'); the U.S. disclosure rules differ between disclosure by passive shareholders (Schedule 13g-filing) and disclosure by active shareholders intending to influence the issuer, or its management (Schedule 13D- filing). The later are mandated to disclose their intentions, see Zohar Goshen \& Gideon Parchomovsky, On Insider Trading, Markets, and "Negative" Property Rights in Information, 87 Va. L. Rev. 1250, 1275 (2001).
} 
rights depend on the fact that violations of disclosure rules have not been corrected. If evidence is strong (which is a precondition for the enforcement of the Premium Claim, see infra), the participants are well advised to give in rather than resist.

\section{Determining the Announcement Premium}

The size of the reward depends on the calculation of the Announcement Premium. On the one hand, the longer the period of time included in that calculation, the greater the risk that other factors that influence the information value (such as defensive measures by management, counterdisclosure by other participants, macro- or micro-economic issues relating to the issuer) impact on the size of the Premium Claim. This uncertainty reduces the defector's risk adjusted return. On the other hand, a period that is too short may not reflect the value of the disclosed information to the market, but noise trading at the announcement date. In the $[t+2]$ window $^{122}$ a sound evaluation of the facts and responsive trading is feasible. While there may be exceptions, I deem a window of [t+/-2] appropriate.

\section{Enforcing the Premium Claim}

The reward model aims at an equilibrium that does not need the enforcement of the Premium Claim since all participants opt in favor of disclosure if the joint holding surpasses disclosure thresholds. However, in the real world, transaction costs from enforcing the Premium Claim may hamper the incentivizing effect of the Premium Claim. If the individual benefits from remaining silent exceed the sum of additional benefits from (early) disclosure minus legal costs for enforcing the Premium Claim, disclosure is unlikely to happen (see Fig 4 supra). The premium claim must be automatic in its legal qualification, ${ }^{123}$ enforced strictly, easily and inexpensively, while avoiding unnecessary involvement of parties with

\footnotetext{
${ }^{122}$ Some empirical studies rely on the $t+2$ window, supra $n .16$.

${ }^{123}$ Any fuzziness will be reflected in the potential defector's risk calculus. Let $\beta \mid 0<\beta<1$ denote the risk from legal uncertainty. Under a reward model in a fuzzy legal environment (i.e. unclear wording etc.), disclosure will happen if $\beta \times P C<\alpha \times P(A ; B)$, i.e. defectors will balance the risk of being deprived of the Premium Claim due to legal peculiarities against the profits from remaining silent.
} 
their own agenda. At the same time, in order to avoid exploitation of the reward scheme, a critical review of the facts is a precondition for granting the Premium Claim to the entity claiming the existence of an unlawful acquisition scheme.

This necessitates three legal requirements:

1) If the facts presented to regulators by the defector provide for evidence as to the existence of an unlawful acquisition scheme regulators should be entitled to impose a lien on a fraction of the participants' shares in order to secure payment of the Premium Claim. ${ }^{124}$

2) If there are more than two participants, in order to improve evidence, a fraction of the Premium Claim (for instance, 10-20\%) may be assigned to the second defector, an even lower fraction to the third defector, and so on, under the condition that there remain some participants to be punished, in order to retain some deterrence effect. Alternatively, the second defector may enjoy lesser administrative or criminal penalties. ${ }^{125}$

3) In a preliminary proceeding, a specialized court, with the regulator acting as claimant on behalf of the first and the second discloser, ${ }^{126}$ establishes whether the defector is entitled to the Premium Claim and which size is appropriate. This depends on whether the defector practiced an open, complete, candid and continued cooperation with authorities that substantially improved the authorities' knowledge about the committed

\footnotetext{
${ }^{124}$ In order to work this lien needs to rank above claims from investor suits. The thorny political issues associated with the implementation may best be explained by understanding the Premium Claim as valuable service to the market and thus investors; without defection investor suits would be all but impossible.

${ }^{125}$ For a parallel in antitrust law, see S.D. Hammond, Measuring the Value of Second-In Cooperation in Corporate Plea Negotiations, online http://www.justice.gov/atr/public/speeches/speech hammond.htm (last visited Novembner 2009): Under US law, discount re penalties of 30\%-35\% for the second; the European Commission "will determine in any final decision adopted at the end of the administrative procedure the level of reduction an undertaking will benefit from, relative to the fine which would otherwise be imposed. For the: - first undertaking to provide significant added value: a reduction of $30-50 \%$, - second undertaking to provide significant added value: a reduction of 20-30\%, - subsequent undertakings that provide significant added value: a reduction of up to $20 \%$." See EU Leniency Notice, supra n. 60, ף26; Wils (2007), supra n. 60, at 10. For a strict 'winner takes all' approach Spagnolo (2007), supra n. 59, at 15 et seq.; Spagnolo (2004), supra n. 71; Spagnolo (2000), supra n. 71 , sub 4.1 .

${ }^{126}$ Public prosecutors fulfill a similar function in traditional criminal proceedings.
} 
violation. ${ }^{127}$ Only if hard facts are provided, the evidence withstands court scrutiny sufficiently in order to punish the fellow wrongdoers. The later is necessary to deter future violations (commonly referred to as desistance). ${ }^{128}$

If the Premium Claim is the defector's prey, we can reasonably expect that the facts can be established with certainty: virtually all communication will be available on tape, time, date and other details of agreements are somewhere safely stored and registered, widely-spread amnesia of the participants will vanish. However, in the absence of early confessions (which may be more likely in light of good evidence) the Premium Claimdoes not change the fact that judges and juries must evaluate, and exercise judgment based on, these facts.

\section{Exploiting the System \& Constitutional Concerns ${ }^{129}$}

The downsides of a reward scheme do not go unnoticed.

\section{Reduced deterrence by lower fines?}

A reward scheme could encourage secret acquisition schemes since it generates a drastic reduction in the expected fines. In our model, any participant $A$ and $B$ as perennial player is likely to balance the profits made from defection against fines in cases where it were too slow to defect. If the reward of Scheme 1 was too high, it set off penalties in Scheme 2, and so on. Such a reward scheme would create incentives to engage in hidden acquisition schemes rather than preventing it. Giancarlo Spagnolo has shown that complete deterrence without public investigation may be achieved if the fines are sufficiently but finitely large, and if the whistleblower's reward is lower than the sum of fines paid by the other

\footnotetext{
${ }^{127}$ While the former qualitative requirements are the joint requirements of the US DOJ and the European Commission for antitrust leniency, only the European Commission requires a substantial improvement in knowledge.

${ }^{128}$ See J. Harrington, Optimal Corporate Leniency Programs, manuscript, John Hopkins University (7/2005), online http://www.econ.jhu.edu/pdf/papers/WP527harrington.pdf (last visited November 2009).

${ }^{129}$ Please note that similar arguments are used in the discussions surrounding Whistle Blowing in securities law, Crown Witnesses in the criminal justice system, and Leniency Programs in antitrust law.
} 
wrongdoers. ${ }^{130}$ My reward model (Table 2) meets this condition: the reward PC is always lower than the fines paid by the non-defectors because the sum of fines (in Spagnolo's meaning) consists of $P C+F(A ; B)$, with $F$ being any administrative penalties, damages to investors, etc. added to the Premium Claim (PC) that is paid to the defector.

\section{Benefits from Violating the Law?}

If, from the individual's perspective, violating the law may turn out to be beneficial, honest citizens are punished for their honesty. This moral concern disregards two important aspects. First, disclosing major shareholdings serves a purpose which is providing the market with information on firm undervaluation that it would otherwise miss. The defector is reimbursed for its information service. The Premium Claim does not only grant benefits for wrongful deeds, but also reimburses the defector for its reputational loss in the 'criminal community' due to disclosure. One may argue that honest citizens would not discount the defector's reputation for its information production; instead, they may assign rewards to the defector. However, the rewards to be received by the honest (such as reputation, future business, etc.) lie in the future and are discounted for that very reasons (see above), while the defector's loss is imminent. Facing the alternative of rules without efficient enforcement, where all wrongdoers get away, and of rules with efficient enforcement, where one wrongdoer gets free and the others are caught, the latter alternative is the preferable.

Secondly, if the model functions according to plan, the likelihood that the Announcement Claim is ever paid and wrongdoers profit from their deeds is Zero: Up to a certain threshold where the transaction costs exceed the expected future profit from disclosure, the model does not incentivize disclosure (i.e. if the joint threshold slightly exceeds the disclosure threshold). Beyond this level we expect the model to result in an equilibrium under which no participant infringes the law.

${ }^{130}$ Spagnolo, (2000), supra n. 71, sub 3.2 and 3.3; Spagnolo, Divide et Impera, (2004), supra n. 71; Spagnolo (2007), supra n. 59, at 23 et seq.; Spagnolo's results were experimentally confirmed by Bigoni et al (supra n. 60), at 21 . 
In experiments with reward schemes that meet the Spagnolo conditions (see above) the players still cooperated, albeit on a very low level. ${ }^{131}$ While the deterrence level of a reward policy was four times as high as traditional enforcement and 2.5 times as high as leniency, the good news is that the reward induced at least one participant to defect in almost all cases. If the real world functions like this experimental design, entities nevertheless entering into cooperation are those with the hope of fooling fellow wrongdoers, rather than the market. Transferring this result to the domain of securities law achieves a striking insight: Under a reward policy cooperation is likely to harm fellow participants only. All other entities are provided with the means to recuperate their losses: Administrative fines against non-defectors may reimburse enforcement agencies for their (reduced) efforts, and litigation does the same for harmed investors. While this is not the optimal state of law enforcement - the first best state is complete deterrence with no enforcement costs -, ${ }^{132}$ it comes very close to the very best state as it achieves very high deterrence with low net enforcement costs (after recuperation). Moreover, the experiment showed that the reward policy strongly deters cooperation, the more the longer subjects play. ${ }^{133}$ While the hope that the lessons by costly Premium Claims will eventually erase all misdeeds is too optimistic, rather than punishing honest citizens for their honesty, a reward policy is likely to reduce secret acquisition schemes to the lowest level possible. Only entities that are oblivious to deterrence (irrational actors, fools etc.) and those which in light of their bounded rationality (supra D.I.) underestimate the risk of defection ${ }^{134}$ remain to conspire.

For these entities oblivious to deterrence, traditional public enforcement may supplement the reward model. In the state where the reward model is

\footnotetext{
${ }^{131}$ In the experiment by Bigoni et al (supra n. 60), at 13, 23, traditional ex post enforcement resulted in cooperation in $31.5 \%$ of the cases. While under a leniency scheme (as is currently the law in antitrust) cooperation dropped to $17.8 \%$, under a reward scheme the participants entered into cooperation in only $7.8 \%$ (i.e. only a quarter of the cases as under traditional enforcement).

${ }^{132}$ See Becker (note 4).

${ }^{133}$ Bigoni et al (supra n. 60), at 23 report that in rematches cooperation dropped systemically, to a level that was equal to $1 / 3$ of the initial level.

${ }^{134}$ This might be, for example, due to personal and family relationships.
} 
applied, public enforcement may become a (more) viable as compared to the present state, since as a result of deterrence by the reward model, regulators have few cases to each which they may devote significant resources.

\section{Benefits for the Originator?}

The model presented herein may result in the main activist, organizer or ringleader, i.e. the worst wrongdoer, benefitting from the Premium Claim and from the minor wrongdoings of the remaining participants. On the one hand, granting benefits to the worst wrongdoer may increase deterrence by ensuring that the ringleader cannot be completely trusted, as the ringleader may also lose confidence in the fellow participants' loyalty and disclose the scheme. ${ }^{135}$ Moreover, the organizer's exclusion weakens the likelihood of detection and punishment, since the scheme organizer avails itself to the best information, and its exclusion incentivizes fellows to cooperate more closely with the organizer, as it provides a safe harbor. ${ }^{136}$

On the other hand, the ringleader could coerce discipline over, or use the Premium Claim as an artifice to negotiate more favorable terms from other participants, as it has the best evidence at hand and may rush to disclose at the moment when it considers it objectives achieved. More importantly, granting benefits to the worst wrongdoer for violating the law raises constitutional concerns, and is questionable in terms of morality. ${ }^{137}$ In addition, it may provide perverse incentives, by inducing the set-up of the scheme in order to profit from the Premium Claim, rather than from an overall increase of the stock price due to superior information production. In some jurisdictions, these paramount considerations account for exclusions of cartel organizers from, or reductions of, antitrust leniency. ${ }^{138}$

\footnotetext{
${ }^{135}$ See Leslie, Cartel Stability (2006), supra n. 58, at 477 (re price fixing); Spagnolo (2007), supra n. 59, at 14.

${ }^{136}$ Bigoni et al., supra n. 60 , at 20 show that excluding the ringleaders goes along with reduced incentives to disclose.

${ }^{137}$ Wils (2007), supra n. 60, at 31.

${ }^{138}$ The US Department of Justice excludes the leader in, the originator of, or those who have pressured others to join the cartel, Corporate Leniency Policy (supra n. 60), sub A. 6. and Art. 28* of the Sentencing Guidelines (supra n. 60). Under the European Commission's leniency policy "[a]n undertaking which took steps to coerce other
} 
In light of this consideration, the law may exclude the originator from the Premium Claim.

Excluding the originator is unlikely to impact on the incentive-based power in case of the Service Strategy where originator and investment banks are unlikely to opt in favor of early disclosure anyway. (It is here where granting rewards to agents rather than principals is particularly valuable). In the case of the Equity Strategy, one may hope that each participant waits for someone else to take the lead; if all want to retain the reward option, no hidden acquisition will materialize. One may accept the losses with respect to detection associated with the exclusion of the ringleader in order to establish a high level of deterrence and maintain higher (i.e. ethical or constitutional) standards than efficiency.

\section{The Issue of Overenforcement}

Overenforcement may become an issue in three variants: A smoothing effect on takeover activity, erroneous prosecutions and convictions of innocent firms, and preventing firm activity at the border but within legality.

\section{Erroneous convictions?}

Erroneous convictions (so-called Type I-errors) of innocent firms or individuals provide the most serious threat to the acceptance of an enforcement system within society. However, within developed legal systems, false convictions are less likely than false acquittals. ${ }^{139}$ This is particularly true in the takeover context, where sophisticated investors with sufficient resources to defend their positions rigorously are the subject of regulatory scrutiny.

undertakings to join the cartel or to remain in it is not eligible for immunity from fines. It may still qualify for a reduction of fines if it fulfils the relevant requirements and meets all the conditions therefor." See EU Leniency Notice, supra n. 60, \ 13, 22. In Germany, the Bundeskartellamt excludes from immunity the ringleader of the cartel, Notice no. 9/2006 of the Bundeskartellamt on the immunity from and reduction of fines in cartel cases Leniency Programme - of 7 March 2006, available at www.bundeskartellamt.de (sub Bonusregelung). See Spagnolo (2007), supra n. 59, at 14; Zingales, supra n. 58, at 34, 45.

${ }^{139}$ For antitrust, see Buccirossi \& Spagnolo, Corporate Governance and Collusive Behavior, in Dale W. Collins (Ed.), Issues in Competition Law and Policy, 2007, Antitrust Section, American Bar Association, Chapter XX, sub 4. 
As a particularity of the reward model, crown witnesses are in line to receive multi-million dollar paydays for their testimony. However, the situation is analogous to CEOs being held personally liable, or firms being sued with multiple damages. Courts will adjust.

\section{A Better world?}

As was shown herein, the reward model avoids disadvantages stemming from established enforcement methods of traditional voting rights disclosure rules. From an overall perspective, does it result in a better world?

This is likely the case under two conditions. First, the reward model works best in an environment where disclosure thresholds are high, in relative terms: Very few (non-active) investors would go anywhere near the threshold if they have reason to fear that their stake is reported and the reward scheme is being triggered. The regulatory stigma would be too great. The fallout of potentially draconian enforcement induces nonconspiring, honest investors to circumnavigate the thresholds, with some safety distance. In a low threshold environment, there is little leeway to do so. The mandatory 5\%-threshold provided by U.S. and European law, and the additional 3\%-threshold established in certain European jurisdictions (e.g. Germany) do not pose problems, in that regard.

Secondly, the reward model is most beneficial in a low enforcement environment. Low enforcement does not refer to the quality or strictness of securities law or the respective regulators, but the overall transparency of activities from financial services firm. This is, generally speaking, true with respect to the environment in which participants arrange the hidden acquisition strategies analyzed in this article. It remains to be true even if CCP clearing is established for all standardized derivative contracts on a national level (for example, in the U.S. and Europe): ${ }^{140}$ The influence on someone else's voting rights (other participant, investment bank) which is the undisclosed criteria of both the Equity and the Service Strategy is not put in writing and not part of trading data. In addition, trading transparency

\footnotetext{
${ }^{140}$ For related activities see supra n. 3.
} 
is limited and remains to be limited to the respective domestic level, while said acquisitions are managed on an international scale. ${ }^{141}$ The reward is an inexpensive mechanism which may be implemented on the domestic level, but which impacts on cross-border activities to the same extent as domestic activities.

If the reward model impacts on capital markets and takeover activity to the same extent as Economic Ownership Disclosure, the model does not exhibit advantages while it may come along with transaction and agency costs (litigation, perverse incentives etc.). Any type of disclosure rules smoothes takeover activity to some extent. The reward model results in disclosure only when investments are backed by de facto voting power. Economic Ownership Disclosure (as implemented in the UK and Switzerland) requires disclosure of any economic investment even though the investment does not come along with voting power. These two models differ with respect to the scope of the smoothing effect. While the reward model mitigates solely takeover activity, in addition to takeovers Economic Ownership Disclosure impacts on the price-setting function of the stock markets for corporate stock. Under Economic Ownership Disclosure, the activity of large-scale arbitragers is all but impossible. Again, this argument does only hold water in a low-threshold environment.

\section{Borderline activity?}

A reward model may indeed smooth firms' activity at the border but within legality. Please note, however, that the alternative of infringing the law is not doing nothing, but acting according to the law. Facing the decision of disclosure and no disclosure, the reward model induces firms to apply a pro-disclosure attitude, when planning takeovers. Generally speaking, this result is desirable. If firms need extensive legal resources to craft devious schemes around the law, the scheme is likely to infringe, if not the letter, then at least the spirit of the law. It is an advantage of the reward model (as compared to Economic Ownership Disclosure) that the borderline is

\footnotetext{
${ }^{141}$ An international cross-border centralized CCP clearing is costly; it also means postponing solutions to the future.
} 
clearly set. Economic-only investments through derivatives and indirect holdings remain in the safe harbor.

\section{F. Other Types of Inside Information?}

Albeit not in a technical sense, the knowledge of undisclosed major shareholdings constitutes inside information. This raises the question of whether the model could be equally useful in enforcing other types of mandatory disclosure. I do not think so.

Two aspects ${ }^{142}$ render extending the scope of the reward model doubtful. First, the Premium Claim would inevitably be paid by the shareholder constituency. The issuer's management is most likely to violate disclosure rules. While one could consider civil liability claims against management, civil liability is often insured by the company (i.e. at the costs of the shareholders), or excluded in the corporate charter. Moreover, if one manager defects by early disclosure, the company and its shareholders are likely to suffer from the stress put on the managerial team. Secondly, while there are few viable excuses for violating major shareholding rules, there may be good business reasons (some of which the law accepts) for maintaining secrecy. The reward model is apt for clear cut rules, but creates more harm than good in a fuzzy legal environment.

\section{G. Conclusion}

According to Garret Hardin ${ }^{143}$, when looking for a technical solution, rejection of proposed reforms is based on one of two unconscious assumptions: (i) that the status quo is perfect; or (ii) that, if the proposed reform is imperfect, we presumably should take no action at all. As passivity is also a form of action, doing nothing is impossible. Instead, mankind is asked to use rationality in order to compare the present state of the world with the state that is likely if the reform is adopted.

\footnotetext{
${ }^{142}$ The limited scope of the reward model is not due to the fact that disclosure of ordinary inside information may prompt a negative rather than a positive stock price response. While a positive stock price reaction is the model assumption, disclosure of major shareholdings may also prompt a negative stock price reaction. To the same extent as positive announcement effects, a negative announcement effect enables an assessment of the value of previously undisclosed information.

${ }^{143}$ Garett Hardin, The Tragedy of the Commons, (1968) 162 Science 1243, 1247 et seq.
} 
This article has shown that the status quo of shareholder transparency rules is, in fact, not perfect. As the case for "action" was established, it presented an incentive-based enforcement model for a high-threshold environment. Granting the premium to the first individual or entity that discloses a secret acquisition results in an equilibrium in which the secret acquisition of major shareholdings without disclosure is unlikely to happen. As discoverable advantage, the reward model avoids the negative impact on the pricing function of capital markets as well as the anti-governance / pro-management effects that come along with Economic Ownership Disclosure. While implementing the model faces some real world challenges, indeed, and some market participants may be unable to learn or do not believe in the likelihood of getting caught, rational decisionmaking precludes "the unworkable assumption that only perfect systems are tolerable."144 The reward model is a step in the right direction. Securities Regulators are encouraged to adopt this powerful tool which has been successfully implemented in other fields of law for efficiently enforcement of shareholder transparency rules.

${ }^{144}$ Id., at 1248. 